\title{
Polychaete-parasitizing copepods from the deep-sea Kuril-Kamchatka Trench (Pacific Ocean), with the description of a new Ophelicola species and comments on the currently known annelidicolous copepods
}

\author{
Mercedes Conradi*, $\mathrm{M}^{\mathrm{a}}$ Eugenia Bandera*, Ivan Marin** \& Daniel Martin*** \\ (*) Laboratorio de Biología Marina, Departamento de Zoología, Facultad de Biología. Universidad de Sevilla. \\ Reina Mercedes 6, 41012 - Sevilla, Spain. Fax: 954233480, \\ (**) A.N. Severtzov Institute of Ecology and Evolution of the Russian Academy of Science, Leninsky prosp., \\ 33, Moscow, 117071, Russia. \\ (***) Centre d'Estudis Avancats de Blanes (CEAB - CSIC). Carrer d'accés a la Cala Sant Francesc 14, 17300 \\ Blanes (Girona), Catalunya (Spain). E-mail: dani@ceab.csic.es, Corresponding author.
}

\begin{abstract}
The annelid associated copepods, collectively called annelidicolous, were placed in 21 families. Some genera, such as Ophelicola, are considered phylogenetically isolated and are placed into the order Cyclopoida as incertae sedis. In this paper, we describe Ophelicola kurambia, the second species recorded for the genus and the first for the Pacific Ocean. The single known specimen, a female, was found during the German-Russian deep-sea expedition KuramBio at the deep-sea Kuril-Kamchatka Trench. The new species differs from Ophelicola drachi (known from the Gulf of Biscay, Atlantic Ocean) in being attached to the host through the mandibles instead of maxillae and, specially, in the formula of the antennular armature. The study of the new species contributes to clarify the diagnosis of the genus, which clearly differs from Notomasticola (another incertae sedis genus), and resembles both the most modified clausiids (in the mandibular shape and antennular segmentation) and the clausidiids (in the shape of maxilla). However, it does not contribute to clarify the position of Ophelicola within the order Cyclopoida. The paper includes a list of the known annelidicolous copepods (excluding Monstrilloidae) and summarizes the main trends shown in terms of diversity, distribution and relationships. Currently, 168 species of copepods from to 74 genera and 22 families and 7 incertae sedis (excluding Monstrilloida) are known to be involved in 235 parasitic relationships (mostly ectoparasitic) with polychaetes. Host polychaetes include 156 species belonging to 104 genera from 22 families (plus 14 unknown). About 50\% of these relationships are known from European waters, mainly from shallow depths.
\end{abstract}

Key words: KuramBio, Pacific Ocean, deep-sea, Copepoda, Ophelicola, parasitic, Polychaeta, Opheliidae.

\section{INTRODUCTION}

More than 120 species of Copepoda belonging to at least 21 families, the so called annelidicolous copepods, were reported to be associated with annelids, most of them being external or internal parasites of polychaetes. Some families include annelid symbionts together with free-living members and/or associates of other invertebrates. However, some others are known as exclusive parasites of polychaete hosts (Boxshall and Halsey, 2004; Humes, 1994).

The symbiotic relationships with polychaetes might have evolved independently from various copepod ancestors (Björnberg and Radashevsky, 2011). A comprehensive hypothesis about the relationships involving parasitic copepods has not yet been developed and therefore, placing annelidicolous species into genera and even families is often problematic (Kim et al., 2013). In fact, the definition of some families is rather nebulous and the boundaries among families are sometimes poorly defined, such as those among Clausidiidae Embleton, 1901, Clausiidae Giesbrecht, 1895 and Anomoclausiidae Gotto, 1964 (Boxshall and Halsey, 2004; Humes and Ho, 1967; Kim et al., 2013). This also caused some genera to be phylogenetically isolated due to their unusual features 
In 1978, Laubier described a new genus of annelidicolous copepod collected from an unidentified ophelid polychaete found between 4,706 and 4,475 m depth in the Atlantic coast of France. The genus Ophelicola Laubier, 1978 was considered as phylogenetically isolated due to its unusual features. Thus, it was placed into the order Cyclopoida as incertae sedis (Boxshall and Halsey, 2004).

During the German-Russian deep-sea expedition KuramBio (Kuril-Kamchatka Biodiversity Study) to the Kuril-Kamchatka trench and abyssal plain, two specimens of moderately transformed copepods associated with polychaete worms were collected. Parasitic copepods from polychaete hosts are seldom reported, likely because their very low prevalence. Usually, these parasites are found only after observing large numbers of potential hosts (Kim et al., 2013), which is a particularly difficult task in the deep-sea. Accordingly, in this paper we describe one of the specimens as a new species of Ophelicola, despite having found a single female, and discuss whether this new discovery provides new insights in the relationship of Ophelicola within the cyclopoid families. Unfortunately, the second annelidicolous copepod, belonging to the genus Anomopsyllus G.O. Sars, 1921, was in very poor conditions and, thus, it could not be formally described. This paper also includes a list of the known annelidicolous copepods (excluding Monstrilloidae) and summarizes all known characteristics in terms of diversity of both the symbionts and the hosts, type of relationship and bathymetrical and geographical distribution.

\section{MATERIAL AND METHODS}

The polychaete hosts were collected during the KuramBio Expedition 2012 to the KurilKamchatka Trench and abyssal plain, with the help of the supranet of the epibenthic sledge EBS-S or the box corer GKG, both operated from the R/V SONNE-223. Infested host were extracted from sediments collected in stations 223-3-9 (4987 - $4991 \mathrm{~m}$ depth) and 2-5A (4869 $\mathrm{m}$ depth), carefully washed on board, photographed alive, and then fixed in $70 \%$ ethanol.

In the laboratory, the copepods were extracted from the hosts, dissected in lactic acid prior to staining with Chlorazol black E (Sigma ${ }^{\circledR}$ C-1144), examined as temporary mounts in lactophenol, and finally sealed with Entellan as permanent mounts. Drawings were made with the help of a camera lucida attached to a Leica DMLB differential interference microscope. Body length was measured from the anterior margin of the rostrum to the posterior margin of the caudal rami. All appendage segments and setation elements are named and numbered according to Huys and Boxshall (Huys and Boxshall, 1991).

The dissected holotype is deposited in the Museo Nacional de Ciencias Naturales of Madrid (MNCN), Spain.

\section{RESULTS AND DISCUSSION}

\subsection{Taxonomic account}

Subclass Copepoda

Order Cyclopoida

Incertae sedis

Genus Ophelicola Laubier, 1978 
Diagnosis (redefined): Body of adult female transformed by swelling and fusion of free pedigerous somites. Prosome comprising cephalothorax incorporating 1 st pedigerous somite and swollen 2nd to 4th pedigerous somites. Urosome distinct, comprising partly swollen 5th pedigerous somite fused to genital somite, and 4 free abdominal somites. Genital apertures paired, located posterolaterally on genital somite. Caudal rami with 6 setae.

Rostrum weakly developed. Antennule 5-segmented, distal 3 segments homologous, with XXI-XXIV, XXV and XXVI-XXVIII; armature 4(5), 16(14), 4+aesthetasc, $2+$ aesthetasc, 7+aesthetasc. Antenna uniramous, 4-segmented with coxa and basis fused to form coxobasis bearing single seta; 1st endopodal segment with 1 mid-margin seta, 2nd with 4 elements sometimes including 1 claw, 3rd with 7 elements; exopod lacking. Entognathous, with mouthparts arranged in perioral depression. Mandible small, consisting of a strongly scleroterized gnathobase with articulated distal portion denticulate or plumose. Maxillule lobate, with 5-9 setae. Maxilla 2-segmented, comprising large unarmed syncoxa and basis; basis with basal naked seta, produced into trifid claw-like process and articulated bifid claw. Maxilliped reduced, sometimes located in transverse groove on surface of cephalothorax, indistinctly 3-segmented, 1st segment unarmed, 2nd with setulose seta, and 3rd smallest, bearing short naked seta and small spine.

Swimming legs 1 to 4 ventrally on somites. Intercoxal sclerite in leg 1 only. Legs 1 to 4 biramous, with 3-segmented rami. Spine and seta formula as in Table 1.

Inner basal seta absent on leg 1. Inner coxal setae absent in all legs. 5th leg small, located laterally on somite; 2-segmented with protopodal segment more or less separate from somite and bearing outer seta: exopodal segment with 3 setae. 6th legs represented by paired opercula in female, sometimes with 1 seta. Egg sacs unknown.

Type species: Ophelicola drachi Laubier, 1978.

Remarks: The original description of Ophelicola pointed out the similarities with the family Clausidiidae in the general structure of the maxillae and swimming legs. However, Ophelicola lacks armature in the maxillar syncoxa, which is armed in clausidiid genera (except for Conchyliurus Bocquet \& Stock, 1957 and Hippomolgus G.O. Sars, 1917). Except for Hyphalion Humes, 1987, Conchyliurus, and Hermadona Ho \& Kim, 2004, most female clausidiids have well-developed 4-segmented maxillipeds (Ho and Kim, 2003), contrarily to the rudimentary limbs of Ophelicola females. Furthermore, the antennules of the Clausidiidae, with the exception of Hermadona, Conchylirius, and Hersilioides Canu 1888, are 7segmented (Boxshall and Humes, 1987; Ho and Kim, 1990, 2003, 2004). Moreover, the derived structure of the mandible excludes Ophelicola from the Clausidiidae and indicates a possible relationship with the Clausiidae (Boxshall and Halsey, 2004). In fact, the mandible and the antennule segmentation of Ophelicola resemble that of the most modified genera of this family (such as Boreoclausia Kim et al. 2013, Vivgottoia, Kim et al. 2013, and Sheaderia $\mathrm{Kim}$ et al. 2013). However, these genera have also very reduced and modified legs 1-4, present the typical clausiid maxillule and maxilla, and have a single free abdominal segment. The clausiid genus Spionicola Bjornberg \& Radashevsky, 2009 shares the 5-segmented antennules with Ophelicola (Björnberg and Radashevsky, 2009), but clearly differs in all remaining characteristics. Ophelicola resembles the clausiid genus Rhodinicola Levinsen, 1878 in having 3-segmented rami of legs 1-4 and in lacking posterior median element at the basis of leg 1 (Björnberg and Radashevsky, 2011). However, most oral appendages of Ophelicola (i.e. mandible and maxilla) differ from the typical clausiid form (Boxshall and Halsey, 2004).

Finally, the incertae sedis genus Notomasticola Kim et al. 2013 clearly differs from Ophelicola in having 1-segmented abdomen, 4-segmented antennule, antennal armature, 
reduced oral appendages lacking maxilliped, 2-segmented rami of legs 1-3, reduced leg 4, and 2-segmented leg 5 (Kim et al., 2013).

Therefore, nearly forty years later from its description, the genus Ophelicola, cannot be placed with confidence in any existing family, and should still be considered as incertae sedis within Cyclopoida until a full cladistic analysis of the annelidicolous families, ideally incorporating molecular data as they become available, could be carried out.

Ophelicola kurambia sp. nov.

(Figures 1-4)

Material examined: MNCN 20.04/10007: 1 female holotype from KuramBio, r/v SONNE-223, station 223-3-9, gear EBS-S, date: 05-08-2012, depth 4987-4991 m, 47 $14.6^{\prime} \mathrm{N}$ $154^{\circ} 42.88^{\prime} \mathrm{E}, 47^{\circ} 14.86^{\prime} \mathrm{N} 154^{\circ} 43.18^{\prime} \mathrm{E}$.

Female: Body slightly transformed cyclopiform, by swelling and partial fusion of prosomal somites (Figures 1A, 1B). Total body length of female $1557 \mu \mathrm{m}$ (measured from anterior margin of cephalic somite to posterior margin of caudal rami on holotype in lactic acid), maximum width $586 \mu \mathrm{m}$. Prosome typically comprising cephalothorax incorporating first pedigerous somite and free 2 nd to 4 th pedigerous somites. Prosome length/width ratio $=$ 1.78:1 Prosome/urosome length ratio $=2.25: 1$. Urosome 5-segmented (Figure 1C) comprising 5 th pedigerous somite, genital double-somite, and 3 free abdominal somites. 5th pedigerous somite much smaller than preceding pedigers, wider than long 92x304 $\mu \mathrm{m}$. Genital double somite (Figures 1A, 1C) nearly rounded and somewhat inflated, $453 \mu \mathrm{m} \times 489.6 \mu \mathrm{m}$, wider in middle. Genital areas located ventrolaterally at end of genital double somite. Each genital area (Figure 1F) with 1 short plumose seta. Egg sacs not seen. 3 free abdominal somites, each

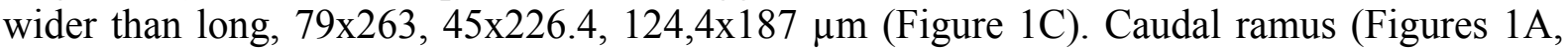
1C), $85 \mu \mathrm{m}$ long, twice longer than wide, with 6 terminal setae. Outer lateral and dorsal setae naked, similar in length. Outermost and two median terminal setae broken; innermost terminal seta very small, naked. Urosome with minute setules (Figure 1C).

Rostrum (Figure 2B) broad, with truncate anterior margin. Antennule (Figure 1E) about $220 \mu \mathrm{m}$ long, with 5 segments measuring (along posterior, non-setiferous margin): 32 (68 $\mu \mathrm{m}$ along anterior margin), 99, 29, 22, and $34.6 \mu \mathrm{m}$, respectively. Formula for armature: $5,14,4+$ aesthetasc, $2+$ aesthetasc and $7+$ aesthetasc. Except for 1 barbed seta on third segment, all setae naked.

Antenna (Figure 2A) uniramous and 4-segmented, $184 \mu \mathrm{m}$ long (terminal setae excluded), with 1st segment longest. 1st segment with 1 long seta, spinulose on inner margin and setulose on outer. 2nd segment with 1 weakly setulose seta, 3 setules and tiny setules close to insertion of 3rd segment. Outer corner of 3rd segment with patch of setules, inner corner with 5 elements: 1 setule, 1 barbed spine, 1 naked seta, 1 strong claw with strong curved spines near tip, and 1 long naked seta. Segment 3 smaller, articulating with segment 2 proximally, somewhat displaced on lateral side, with 7 setae ornamented as figured, 1 of them longer than total length of antenna. Labrum (Figures 2E, 2F) with patch of surface setules, with 1 pair of curved digitiform processes in middle of posterior margin, and membranous areas on each side of process, each membranous area with rounded process entirely covered with setules.

Mandible (Figure 2G) reduced and small, consisting of a strongly scleroterized gnathobase on which inserts a distal portion; articulation clearly visible. Basal part conicalshaped, with membranous flange along medial (posterior) margin. Distal portion short dagger-shaped, no sclerotized but densely plumose. 
Maxillule (Figures 2C, 2D) complex, lobate but without clear distinction between lobes ( 1 setulose), tapering towards apex. Armature of maxillule with 10 elements, 9 setae with length and ornamentation as figured and 1 rounded element.

Maxilla (Figure 2H) 2-segmented, comprising large unarmed syncoxa. Segment 2 sclerotized with basal naked seta, produced into trifid claw-like process, articulated bifid claw-like process (widest claw with long setules on surface), and 1 naked seta.

Maxilliped (Figure 2I) small, $54 \mu \mathrm{m}$ long; 3-segmented with segment 1 unarmed, segment 2 with 1 spinulose seta, and segment 3 smallest, bearing 1 short naked seta and 1 small spine.

Swimming legs 1-4 (Figures 3A-C), located ventrally on somites, biramous, with 3segmented rami. Spine and seta formula listed in Table 2.

Inner basal seta absent on leg 1. Basis with outer naked seta in legs 1-4. Both, endopodal and exopodal segments with spinules at outer corner. Setae and spines very long.

Leg 5 (Figure 1D) 2-segmented but proximal protopodal segment incorporated into somite, with 1 posterolateral seta. Free distal segment (exopod) small, nearly as long as wide, $20.3 \times 27 \mu \mathrm{m}$; armed with 1 subterminal seta and 2 terminal setae, the outer, the largest.

\section{Male: Uknown}

Etymology: The specific name derives from "KuramBio", the acronym of the expedition during which the copepod was collected. Gender feminine.

Distribution: Known only from the type locality at the Northwest Pacific, abyssal Kuril-Kamchatka Trench area.

Ecology: The observed specimen was attached to the skin of a non identified opheliid polychaete, using its left and right maxillae together as pincers.

Remarks: The genus Ophelicola was erected by Laubier (1978) to include a species parasitizing an opheliid polychaete, $O$. drachi, found in the abyssal plain of the Gulf of Biscay (Atlantic coast of France) at about $4.500 \mathrm{~m}$ depth. To date, no other species of this genus has been discovered. Ophelicola kurambia sp. nov. is, thus, the second known species and was also found deeper than 4,000 $\mathrm{m}$ but in the abyssal plain of the Kuril-Kamchatka Trench (Northwest Pacific Ocean).

Both species are ectoparasites of an unidentified opheliid, however, O. kurambia sp. nov. was attached to the host through its maxillae, while $O$. drachi was attached through the mandibles (Laubier, 1978).

Both species also differ in the formula for the antennular armature $(5,14,4+$ aesthetasc, $2+$ aesthetasc and 7 setae + aesthetasc in O. kurambia sp. nov.; 4, 16, $4+$ aesthetasc, $2+$ aesthetasc, $7+$ aesthetasc in $O$. drachi). As for the antenna, both species present the same number of elements per segment $(1,1,4,7)$, but the 3 rd segment has 3 setae plus 1 claw in $O$. kurambia sp. nov. and 4 setae in $O$. drachi. The formula proposed by Boxshall and Halsey (2004) for the genus (1, 1, 3+1 claw, $4+3$ claws) do not match with the two species studied. Both species show a mandible strongly sclerotized, but in the new species the gnathobase has a short dagger-shaped densely plumose, instead of the large blade distally denticulated of $O$. drachi.

The maxillule of $O$. kurambia sp. nov. has 9 setae plus 1 rounded distal element, and 1 setulose lobe tapering towards the apex, while $O$. drachi possesses 5 setae and a rounded distal lobe. 
The maxilla of $O$. kurambia sp. nov. possesses 1 bifid, pincer-like element articulated at base, 1 trifid claw-like process and 2 naked setae. In turn, the maxillar distal segment of $O$. drachi presents a basal seta and a complex system of claws, one of them bifid and the other one represented by a truncated stump with a pointed process distally according to Laubier (1978), while Boxshall and Halsey (2004) described the maxilla of Ophelicola with a basis produced into a trifid claw-like process bearing 1 seta.

The original description of $O$. drachi points out that maxillipeds are located in a transverse groove on the surface of the cephalothorax, as confirmed by Boxshall and Halsey (2004). However, during the dissection of O. kurambia sp. nov., this circumstance has not been observed.

The armature formula for legs 1-4 is similar in both species. Since the table showing the legs' ornamentation (Table 1 in Laubier, 1978) contains some errors, the main discrepancies have been here inferred from the legs illustration and are detailed in Table 3. Moreover, in the Laubier (1978) description, legs 1-4 have all setae naked and all spines smooth, while the setae are plumose and the spines are spinulose in O. kurambia sp. nov.

Family Nereicolidae Claus, 1875

Genus Anomopsyllus Sars G.O., 1921

Diagnosis: Body with small cephalosome, inflated trunk and 2-segmented urosome, 4segmented maxilliped with stout terminal segment; unmodified, simple setae on 2- or 3segmented antenna, and swimming legs reduced or absent. Usually living in association with polychaetes (Kim et al., 2013).

Anomopsyllus sp.

Material examined: 1 damaged female, KuramBio expedition, station 2-5A, box corer GKG, sediment fraction $300 \mu \mathrm{m}, 4869 \mathrm{~m}$ depth. August 2 2012, ID. 356 associated with a non identified Ampharetidae.

Diagnosis: Specimen lacking legs. Oral area seriously damaged. Other body regions damaged too, with non-distinguishable characters.

Distribution: Northwest Pacific, abyssal Kuril-Kamchatka Trench area.

Remarks: Anomopsyllus is composed by 5 species: A. hamiltonae Kim et al., 2013 (legs 1-5 absent), A. bifurcusi Kim et al., 2013 and A. geminus Kim et al., 2013 (only legs 4 and 5 absent, the remaining vestigial), A. abyssorum Laubier 1988 and A. pranizoides Sars 1921 (Legs 1-5 vestigial, the 3 first legs more development than the two latter) (Kim et al., 2013; Laubier, 1988). Our specimen resembles A. hamiltonae in lacking the legs, but the damaged oral area prevented us to define the position of this copepod with respect to the known congeners.

\subsection{Biodiversity of annelidicolous copepods (excluding Montrilloidae)}

Symbiotic copepods are known to live symbiotically with virtually all marine metazoan taxa (Huys and Boxshall, 1991). However, those infesting invertebrates are relatively poorly 
known in comparison with their piscicolous relatives, likely due to the economic interest of this particular group of hosts (O'Reilly, 1991). More specifically, eleven families of cyclopoid copepods are recorded exclusively from polychaete hosts, but several other families include one or more polychaete symbionts (Boxshall and Halsey, 2004).

Twenty two copepod families and seven incertae sedis (excluding Monstrilloida) are currently known to be involved in 235 parasitic relationships with annelid polychaetes (Table 4). These copepods belong 168 species from to 74 genera. The most representative family are the Herpyllobiidae, with 50 relationships $(21.5 \%)$, followed by Clausiidae and Nereicolidae with $37(15,9 \%)$ and $34(14.6 \%)$, respectively, Sabelliphilidae with 23 (9.9\%), and Gastrodelphyidae and Xenocoelomatidae with 13 (5.6\%). The remaining families are involved in less than 9 relationships. Most families include only one (41\%) or two $(23 \%)$ polychaete parasitic copepod genera, and there is only one, the Clausiidae, which include 17 genera. A similar pattern is shown by the species per genera, as most of them include a single polychaete parasitic species (59\%), only a $18 \%$ include two species and the remaining $21 \%$ include from 3 to a maximum of 17 (in Herpyllobius Steenstrup \& Lutken, 1861) species. This apparently supports a high degree of specificity in the relationships between the annelidicolous copepods and their polychaete hosts, however the observed pattern may also be caused by the lack of adequate observations.

In turn, these copepods are associated to 156 species of polychaetes belonging to 104 genera from 22 families (plus 14 unknown polychaetes). The family most commonly found to be infested by copepods is the Polynoidae (63 relationships, $27 \%$ ), followed by Sabellidae and Terebellidae (with 30, 12,7 \%, and 24, $10.2 \%$, relationships, respectively). The remaining polychaete families include less than $9 \%$ of the known relationships and, even, eight of them include less that 1\% (five and three families in two and one relationships, respectively). Most families include only one (35\%) or two $(17 \%)$ parasitized polychaete genera, and there is only one, the Polynoidae, which include 22 genera. This trend is even more exaggerated when analysing the number of species per genera, as $73 \%$ include a single parasitized species and only $17 \%$ include two species. The remaining $11 \%$ include thee or more species, and the maximum is nine in the case of the polynoid genus Harmothoe Kinberg, 1856. Again, the family Polynomial included the highest number of infested species, 36 , which represents about $25 \%$ of the total. Curiously enough, the Polynoidae is also the family including more symbiotic polychaete species, about $56 \%$ of the known ones, this representing about $60 \%$ of the relationships (Martin and Britayev, 1998).

Concerning the type of relationships, when reported copepods are most often parasites and only four species, have been reported as commensals (Table 4). In the case of Bulbamphiascus imuse, for instance, the polychaete hosts shared their tubes with 1-4 copepods each (males, females and/or copepodites) and the commensals were placed between worm and tube (Moore and O'Reilly, 1993). The parasitic annelidicolous copepods, in turn, may be ectoparasitic (i.e. living on the exterior of the host), mesoparasitic (i.e. living partly embedded in its host, usually with the anterior end forming an anchor process) or endoparasitic (i.e. living on the interior of the host). Most parasitic annelidicolous copepods are ectoparasites $(158,68 \%)$, followed by mesoparasites $(48,20.5 \%)$ and endoparasites $(14$, $6 \%$ ). Moreover, there are 12 species whose type of relationship has either not been reported or we have been unable to locate them. In some cases, the association with polychaete hosts may be circumstantial or has been just inferred, as the putative symbiotic copepods were obtained from washing of other organisms. This may be the case, for instance, of Pseudanthessius gracilis, Parangium abstrusum and Stokella indica, in which the association with polychaetes is assumed by comparing them with the most closely related species.

Ophelicola kurambia sp. nov. is a typical ectoparasitic species, which remain attached to its polychaete host with the help of the maxillae. Nothing more is known on this species 
except the depth range and the geographical location of the collection site, and this is a common situation for most annelidicolous copepods, as some species remain unrecorded since their original description (often very old dated). As stated by O'Reilly (1991) a careful examination of appropriate hosts is often all that is required to rediscover these species or to find new species to be described, as in the case of $O$. kurambia sp. nov.

Like our new species, some annelidicolous copepods were also reported from very deep waters, i.e. deeper than $2000 \mathrm{~m}$. Among them, there are Trophonophila bradii, Gottoniella andeepi, Anomopsyllus abyssorum, Vectoriella ramosae and the other known species of Ophelicola, O. drachi (Table 4), but O. kurambia sp. nov. and the damaged specimen of Anomopsyllus found at the Kuril-Kamchatka Trench occurred at the deepest known bottoms (almost $5000 \mathrm{~m}$ depth). It must be pointed out, however, that we have not been able to find references to the collection site depths for almost half of the species included in Table 4. Taking this into account, most other species $(\approx 30)$ are reported from shallow waters around $100 \mathrm{~m}$ depth or less, wile the remaining 18 occur between 200 and $700 \mathrm{~m}$ depth). Deep waters are by far poorly studied compared with shallow ones, but the few studies addressed to these ecosystems seem to confirm that they may be very favourable to the establishment of such intimate relationships.

Concerning the biogeographical distribution, among the 233 known relationships, almost $44 \%$ have been reported from European waters. Accordingly, more than $58 \%$ of all them occurred in the North Atlantic Ocean (including European and American coasts). The following region including more reports of anelidicolous copepods is the Indian Ocean (including Red Sea) with about $16 \%$. The Antarctic Ocean, the Mediterranean Sea and the North Pacific Ocean include percentages of around 8 - $10 \%$, the South Pacific Ocean and the Caribbean Sea around $3 \%$, and the remaining locations (i.e. Black Sea, South Atlantic Ocean, and Arctic Ocean) include less than $1 \%$ (i.e. single report each). The high number of European reports (as well as those from the North Atlantic Ocean) may likely obey to a bias caused by the fact that these coasts have been more intensively studied. Although relatively less studied, the Indian Ocean also includes a relevant percentage of reports, which confirms this area as a hot spot of biodiversity.

The precise number of copepod species is difficult to determine, while the parasites of fish have been estimated to be around 1,600 -1,800 species (Mariniello, 2010). Taking into account the wide range of hosts and the ubiquity of the invertebrate symbiotic copepods, there is no doubt that the real number of species may be as high or even higher that those associated to fish hosts, and that the annelidicolous species may substantially contribute to this number in the near future.

\section{ACKNOWLEDGEMENTS}

The KuranBio project was undertaken with the financial support of the PTJ (German Ministry for Science and Education), grant 03G0223A. We would like to thank Drs. Angelika Brandt and Marina Malyutina for giving us (IM) the opportunity to participate in the project and for processing the material. Thanks must also be extended to the captain and the crew of the RV "SONNE". This study is partly supported by the grants of the President of the Russian Federation MK-4481.2014.4 and the Russian Foundation of Basic Research 12-04-00540-a and 14-04-10183-k, and is a contribution of DM to the Consolidated Research Group 2014SGR120, funded by the "Generalitat de Catalunya", and to the Spanish State Research Project CTM2013-43287-P. This is the KuramBio publication \# 19. 


\section{REFERENCES}

Barnard, K.H., 1948. New records and descriptions of new species of parasitic Copepoda from South Africa. Ann. Mag. Nat. Hist. 12, 242-254.

Björnberg, T.K.S., Radashevsky, V.I., 2009. A new genus and a new species of Clausiidae (Crustacea, Copepoda) parasitic on Dipolydora armata (Polychaeta, Spionidae) in Brazil. Pap. Av. Zool. 49, 249-256.

Björnberg, T.K.S., Radashevsky, V.I., 2011. A new species of Rhodinicola (Copepoda, Clausiidae), parasitic copepod of the shell-boring polychaete Polydora brevipalpa (Annelida, Spionidae) from the Sea of Japan. Invert. Zool. 8, 103-114.

Bocquet, C., Bocquet-Vedrine, J., L'Hardy, J., 1968. Analyse des rapports du copépode parasite Xenocoeloma alieni (Brumpt) et de son hôte Polycirrus caliendrum Claparède. Cah. Biol. Mar. 9, 285-296.

Bocquet, C., Stock, J.H., 1958. Copépodes parasites d'invertébrés des côtes de France. VI. Description de Paranthessius myxicolae nov. sp., copépode semi-parasite du Sabellidae Myxicola infundibulum (Rénier). Proc. Koninklijke Nederl. Akad. Wetensch., Ser. C, Biol. Sci., Amsterdam 61, 243-253.

Bocquet, C., Stock, J.H., 1963. Copépodes parasites d'invertébrés des côtes de France. XVI. Description de Pseudoclausia longiseta n. sp. (Copépode Cyclopoïde, famille des Clausiidae). Proc. Koninklijke Nederl. Akad. Wetensch., Ser. C, Biol. Sci., Amsterdam 66, 139-152.

Bocquet, C., Stock, J.H., Kleeton, G., 1963. Copepodes parasites d'invertebres des cotes de la Manche. X. Cyclopoides poecilostomes associes aux annèlides polychétes dans la région de Roscoff. Archs. Zool. Exp. Gén. 102, 20-40.

Boxshall, G.A., 2001. Copepoda (excl. Harpacticoida), in: Costello, M.J., Emblow, C.S., White, R.J. (Eds.), European register of marine species: a check-list of the marine species in Europe and a bibliography of guides to their identification. Muséum National d'Histoire Naturelle, Paris, pp. 252-268.

Boxshall, G.A., Halsey, S.H., 2004. An introduction to copepod diversity. Ray Society, London.

Boxshall, G., Humes, A.G., 1987. A new species of Hemicyclops (Copepoda: Poecilostomatoida) associated with echiuran worm in Hong Kong. Asian Mar. Biol., 6166.

Bresciani, J., 1964. Redescription of Rhodinicola elongata Levinsen and description of Rhodinicola gibbosa sp. nov., parasitic copepods of maldanid polychaetes. Ophelia 1, 223-234.

Bresciani, J., 1967. Redescription du mâle de Selioides bolbroei Levinsen, avec une note sur la répartition géographique du genre Selioides (Copepoda Cyclopoida). Crustaceana 13, 220-226.

Bresciani, J., Lützen, J., 1966. The anatomy of Aphanodomus terebellae (Levinsen) with remarks on the sexuality of the family Xenocoelomidae nov. fam. (Parasitic Copepoda). Bull. Mus. Nat. Hist. Nat. 37, 787-806.

Bresciani, J., Lützen, J., 1972. The sexuality of Aphanodomus (Parasitic copepod) and the phenomenon of cryptogonochorism. Vidensk. Meddr. dansk. naturh. Foren. 135, 7-20.

Bresciani, J., Lützen, J., 1974a. Melinnacheres ergasiloides M. Sars, a parasitic copepod of the polychaete Melinna cristata, with notes on multiple infections caused by annelidicolous copepods. Ophelia 13, 31-41.

Bresciani, J., Lützen, J., 1974b. On the biology and development of Aphanodomus Wilson (Xenocoelomidae), a parasitic copepod of the polychaete Thelepus cincinnatus. Vidensk. Meddr. dansk. naturh. Foren. 137, 25-63. 
Brumpt, E., 1897. Sur un copépode nouveau (Saccopsis alleni n. sp.) parasite de Polycirrus aurantiacus Grube. C. R. Acad. Sci., Paris 124, 1464-1467.

Carton, Y., 1971. Copépodes parasites de Madagascar I.: Description de Sabellacheres aenigmatopygus n. sp., Copépode parasite de Potamilla reniformis (Polychètes, Sabellida3e). Crustaceana 21, 145-152.

Carton, Y., Laubier, L., 1974. Description de Selioides guineensis sp. n., copépode cyclopoide parasite d'aphroditidae. Archs. Zool. Exp. Gén. 115, 129-139.

Cordell, J.R., 2007. Copepoda, in: Light, S.F. (Ed.), The Light and Smith manual: intertidal invertebrates from central California to Oregon. Univ of California Press, Oregon.

Costanzo, G., Crescenti, N., Calafiore, N., 1996. Copepodid development of Pseudanthessius gracilis Claus, 1889 (Copepoda, Poecilostomatoida, Pseudanthessiidae), a copepod associated with Hydroides elegans (Haswell, 1883)(Annelida, Polychaeta) of Lake Faro (Messina, Italy) as obtained in the laboratory. Crustaceana 69, 295-305.

Dantan, J.L., 1929. Recherches sur le Nereicola ovata Keferstein. Ann. Inst. Océanogr., Monaco 7, 175-197, figs. 171-120.

Delamarre-Debouteville, C., Laubier, L., 1960. Les 'Phyllocolidae', une famille nouvelle de Copépodes parasites d'Annélides Polychètes. C. R. hebd. Séanc. Acad. Sci., Paris 251, 2083-2085.

Delamarre-Debouteville, C., Laubier, L., 1961. Note rectificative. Vie Milieu 11, 690.

Dogiel, V., 1908. Entobius loimiae ng, n. sp., eine endoparasitische Copepode. Zool. Anz. 33, 561-567.

Dudley, P.L., 1964. Some gastrodelphyid copepods from the Pacific Coast of North America.; no. 2194. Am. Mus. Novit. 2194, 1-51.

Gooding, R.U., 1960. North and South American copepods of the genus Hemicyclops (Cyclopoida: Clausidiidae). Proc. U. S. Natn. Mus. 112, 159-195.

Gotto, R.V., 1963. Observations on the structure, affinities and biology of a rare copepod, Eunicicola (formerly Eurynotus) insolens (T. \& A. Scott). Proc. Zool. Soc. Lond. 140, 47-56.

Gotto, R.V., 1966. Entobius hamondi n. sp., a copepod associated with a terebellid worm., 11(2): 156-162. Crustaceana 11, 156-162.

Gotto, R.V., Leahy, Y., 1988. A new annelidicolous copepod, Cyclorhiza megalova n. sp., with comments on its functional biology and possible phylogenetic relationships. Hydrobiologia 167-168, 533-538.

Gravier, C., 1912a. Sur un nouveau genre de Crustacé parasite d'un Syllidien de l'Antarctique sud-américaine (Thylacoides nov. g. sarsi n. sp.). Bull. Mus. Nat. Hist. Nat., Paris 18, 7174.

Gravier, C., 1912b. Sur un type nouveau de Crustacé parasite d'un Serpulien de l'Antarctique sudamericaine (Bactropus ng cystopomati n. sp.). Bull. Mus. Nat. Hist. Nat., Paris 18, 6771.

Gravier, C., 1918a. Contribution à l'étude d'un copépode (Flabellicola neapolitana Gravier) parasite d'un annélide polychète [Flabelligera (Siphonostoma) diplochaitos (Otto)]. Publ. Staz. Zool. Napoli 2, 209-222.

Gravier, C., 1918b. Sur un nouveau copépode (Flabellicola ng neapolitana n. sp.) parasite d'un annélide polychète [Flabelligera diplochaitos (Otto)]. C. R. hébd. Séanc. Acad. Sci., Paris 166, 502-505.

Hesse, E., 1869. Observations sur les Crustacés rares ou nouveaux des côtes de France (dixseptième article). Ann. Sci.s Nat., Sér. Zool. Biol. Anim., Paris 5, 275-308.

Ho, J., 1984. New family of poecilostomatoid copepods (Spiophanicolidae) parasitic on polychaetes from southern California, with a phylogenetic analysis of nereicoliform families. J. Crust. Biol. 4, 134-146. 
Ho, J.-S., Kim, I.H., 1990. Hemicyclops ctenidis, a new Poecilostomatoid copepod (Clausidiidae) associated with a Polychaete in Korea. Korean J. Zool. 33, 231-237.

Ho, J.-S., Kim, I.H., 2003. New clausiid copepods (Poecilostomatoida) associated with polychaetes of Korea, with cladistic analysis of the family Clausiidae. J. Crust. Biol. 23, 568-581.

Ho, J.-S., Kim, I.H., 2004. A new genus of the Clausidiidae (Copepoda: Poecilostomatoida) associated with a polychaete from Korea, with discussion of the taxonomic status of Hersiliodes Canu 1988. Proceedings of the Biological Society of Washington. Proc. Biol. Soc. Wash. 117, 95-105.

Humes, A.G., 1975. Cyclopoid copepods associated with marine invertebrates in Mauritius. Zool. J. Linn. Soc. 56, 171-181.

Humes, A.G., 1985. Poecilostomatoid copepods parasitic in the scleractinian coral genus Goniastrea in the Moluccas. Publs. Seto Mar. Biol. Lab. 30, 277-286.

Humes, A.G., 1994. How many copepods? Hydrobiologia 292-293, 1-7.

Humes, A.G., Doriji, M., 1980. A siphonostome copepod associated with a vestimentiferan from the Galapagos Rift and the East Pacific Rise. Proc. Biol. Soc. Wash. 93, 697-707.

Humes, A.G., Grassle, J.F., 1979. Serpulidicola josephellae sp. nov.(Copepoda, Cyclopoida) from a deep-water polychaete west of Ireland. Crustaceana 36, 309-315.

Humes, A.G., Ho, J.-S., 1967. New cyclopoid copepods associated with polychaete annelids in Madagascar. Bulletin of the Museum of comparative Zoology, 135(7):377-413. Bull. Mus. Comp. Zool. Harward Coll. 135, 377-413.

Humes, A.G., Stock, J.H., 1973. A revision of the family Lichomolgidae Kossmann, 1877, cyclopoid copepods mainly associated with marine invertebrates. Smithson. Contr. Zool. 127, 1-368.

Huys, R., Boxshall, G., 1991. Copepod evolution. The Ray Society, London.

Kim, I.H., 2000. Poecilostomatoid copepods from an intertidal mud flat in the Yellow Sea. J. Nat. Hist. 34, 367-432.

Kim, I.H., 2001a. A new genus and two new species of Copepoda (Poecilostomatoida, Sabelliphilidae) associated with the tubicolous polychaetes in the Yellow Sea. Korean J. Biol. Sci. 5, 1-9.

Kim, I.H., 2001b. A new species of Clausia (Copepoda, Poecilostomatoida, Clausiidae) associated with the polychaete Arenicola brasilliensis Nonato in Korea Hydrobiologia 452, 217-223.

Kim, I.H., 2001c. Redescription of Catinia plana Bocquet and Stock, 1957 and description of two new species of Myzomolgus associated with the sipunculans in Korea. Korean J. Syst. Zool. 17, 71-89.

Kim, I.H., 2005. Two new species of copepods (Crustacea) associated with the sponge Phyllospongia foliascens (Pallas) from the Moluccas. Integr. Biosci. 9, 229-238.

Kim, I.H., Sikorski, A., O'Reilly, M.G., Boxshall, G.A., 2013. Copepods associated with polychaete worms in European seas. Zootaxa 3651, 1-62.

Laubier, L., 1961. Phyllodicola petiti (Delamare et Laubier, 1960) et la famille des Phyllodicolidae, Copépodes parasites d'Annélides Polychètes en Méditerranée occidentale. Crustaceana 2, 228-242.

Laubier, L., 1965. Présence de Nereicola ovatus Keferstein à Banyuls-sur-Mer. Données morphologiques nouvelles. Bull. Mus. Nat. Hist. Nat. 36, 631-640.

Laubier, L., 1970. Rhodinicola thomassini sp. n., un nouveau Copépode parasite d'Annélides Polychètes Maldanidae de l'Océan Indien. Archs. Zool. Exp. Gén. 111, 559-571.

Laubier, L., 1971. Description du mâle du genre Rhodinicola Levinsen (Copépode Clausiidae). Archs. Zool. Exp. Gén. 112, 351-359. 
Laubier, L., 1978. Ophelicola drachi gen. sp. n. un nouveau copépode cyclopoïde abyssal ectoparasite d'Annélides polychètes Opheliidae. Archs. Zool. Exp. Gén., 39-50.

Laubier, L., 1988. Le genre Anomopsyllus Sars, 1921 copépode parasite d'annélides polychètes: A pranizoides Sars, 1921 et $A$. abyssorum nov. sp. Crustaceana 55, 180-192.

Laubier, L., Carton, Y., 1973. Vectoriella ramosae sp. n., un copépode parasite d'annélide polychète en Méditerranée profonde. Archs. Zool. Exp. Gén. 114, 149-158.

López-González, P.J., Bresciani, J., Conradi, M., 2000. Two new species of Herpyllobius Steenstrup \& Lutken, 1861 and a new record of Herpyllobius antarcticus Vanhoffen, 1913 (parasitic Copepoda) from the Weddell Sea, Antarctica. . Polar Biol. 23, 265-271.

López-González, P.J., Bresciani, J., Conradi, M., 2006. New genus, three new species and new records of Herpyllobiidae Hansen, 1892 (Crustacea, Copepoda) parasites of polychaetes from Antarctica. Sci. Mar. 70, 243-259.

Lützen, J., 1964. A revision of the family Herpyllobiidae (parasitic copepods) with notes on hosts and distribution. Ophelia 1, 241-274.

Marchenov, A.V., 2002. Bradophilidae fam. nov. - The new family of mesoparasitic Copepod (Copepoda: Poecilostomatoida) collected from the polychaete Brada villosa from the White Sea. Parasitologia 36, 514-517.

Mariniello, L., 2010. Parasitic and associated copepods. Biol.Mar.Medit. 17, 438-451.

Martin, D., Britayev, T.A., 1998. Symbiotic polychaetes: Review of known species. Oceanogr. Mar. Biol. Ann. Rev. 36, 217-340.

Moom, S. ., Kim, I.H., 2010. Three new species of Hemicyclops (Copepoda, Cyclopoida, Clausidiidae) from Korea. Korean J. Syst. Zool. 26, 279-293.

Moore, C.G., O'Reilly, M.G., 1993. Commensalism between the polychaete, Capitella capitata (Fabricius), and the copepod, Bulbamphiascus imus (Brady)? Mar. Poll. Bull. 26, 653-654.

O'Reilly, M.G., 1991. A guide to polychaete-infesting copepods from British waters. Porcupine Newsl. 5, 63-70.

O'Reilly, M.G., 1995. A new genus of copepod (Copepoda: Poecilostomatoida) commensal with the maldanid polychaete Rhodine gracilior, with a review of the Family Clausiidae. J. Nat. Hist. 29, 47-64.

O'Reilly, M.G., 1999. Notes on copepod parasites of polychaete worms in Scottish waters; Including the first UK records of the Californian copepod Spiophanicola spinosus Ho, 1984 (Poecilostomatoida: Spiophanicolidae). Glasgow Naturalist 23, 46-47.

Sars, G.O., 1870. Bidrag til Kundskab om Christianiafjordens Fauna: Efter Forfatterens efterladte Manuskripter samlet og udgivet af hans Son G. O. Sars. Johan Dahl, Christiania.

Sars, M., 1862. Beskrivelse med Afbildninger af fire nye parasitiske Copepoder. Beretning om et nyt lernaealignende Krebsdyr, Sabellacheres gracilis Sars. . Forhandl. Vidensk. Selsk. Christiana Forh. 1862, 134-143.

Sebastian, M.J., Pillai, N.K., 1974. Two New Genera of Clausiid Copepods, Indoclausia and Stockia. Crustaceana, 80-88.

Southward, E.C., 1964. On three new cyclopoid copepods associated with deep-water polychaetes in the north-east Atlantic. Crustaceana 6, 207-219.

Stock, J.H., 1959. Copepoda associated with Neapolitan invertebrates. Naples, Stat. Zool. Pubbl. 31, 59-75.

Stock, J.H., 1960. Sur quelques copépodes associés aux invertébrés des côtes du Roussillon. Crustaceana 1, 218-257.

Stock, J.H., 1979. Serpulidicolidae, a new family of Copepoda associated with tubicolous polychaetes, with descriptions of a new genus and species from the Gulf of Mexico. Mem. Hourglass Cruises 5, 1-11. 
Stock, J.H., 1986. Cases of hyperassociation in the Copepoda (Herpyllobiidae and Nereicolidae). Syst. Parasitol. 8, 71-81.

Stock, J.H., 1988. A bizarre parasitic copepod (nereicoliform Poecilostomatoida) from the Great Barrier Reef. Tropical Zool. 1, 217-222.

Stock, J.H., 1989. Présence de la famille des Serpulicolidae, Copépodes Poecilostomatoida associés aux Polychètes Serpulidés, dans l'Indo-Pacifique: description d'une nouvelle espèce d'Indonésie. Indo-Malayan Zool. 6, 165-171.

Stock, J.H., 1995. Two new poecilostomatoid copepods (Crustacea) associated with thge polychaeta Spirobranchus) from The Seychelles. J. African Zool. 209, 77-88.

Stock, J.H., 1996. Two new species of copepoda parasitic on polynoid polychaetes. Crustaceana 69, 438-445.

Stock, J.H., Humes, A.G., Gooding, R.U., 1964. Copepoda Associated with West Indian Invertebrates. IV. The Genera Octopicola, Pseudanthessius and Meomicola (Cyclopoida, Lichomolgidae). Stud. Fauna Curaçao Carib. Isl. 18, 1-74, figs. 71-24.

Suárez-Morales, E., Boxshall, G.A., 2012. A new species of Sabellacheres M. Sars, 1862 (Copepoda: Gastrodelphyidae) from a deep-water benthic polychaete in Antarctic waters, with a key to the species of the genus. Syst. Parasitol. 83, 65-75.

Suarez-Morales, E., Carrera-Parra, L.F., 2012. A new species of the rare endoparasitic copepod Entobius (Copepoda: Entobiidae) from Mexico with a key to the species of the genus. Folia Parasitol. 59, 221-228.

Walter, T.C., Boxshall, G., 2014. World of Copepods database. http://www.marinespecies.org/copepoda/aphia.php? $\mathrm{p}=$ taxdetails\&id=347551.

Williams, L.W., 1907. List of the Rhode Island Copepoda, Phyllopoda, and Ostracoda, with new species of Copepoda. Ann. Rept. Comm. Inland Fish. Rhode Island. 37, 69-79.

Wilson, C.B., 1923. A new genus and species of parasitic copepod from Lower California. Am. Mus. Novit. 81, 1-4.

Yáñez-Rivera, B., Suárez-Morales, E., 2008. Pseudanthessius tortuosus Stock, 1967 (Copepoda: Cyclopoida) from the amphinomid polychaete Hermodice carunculata (Pallas) in the western Caribbean. Syst. Parasitol. 69, 211-220. 


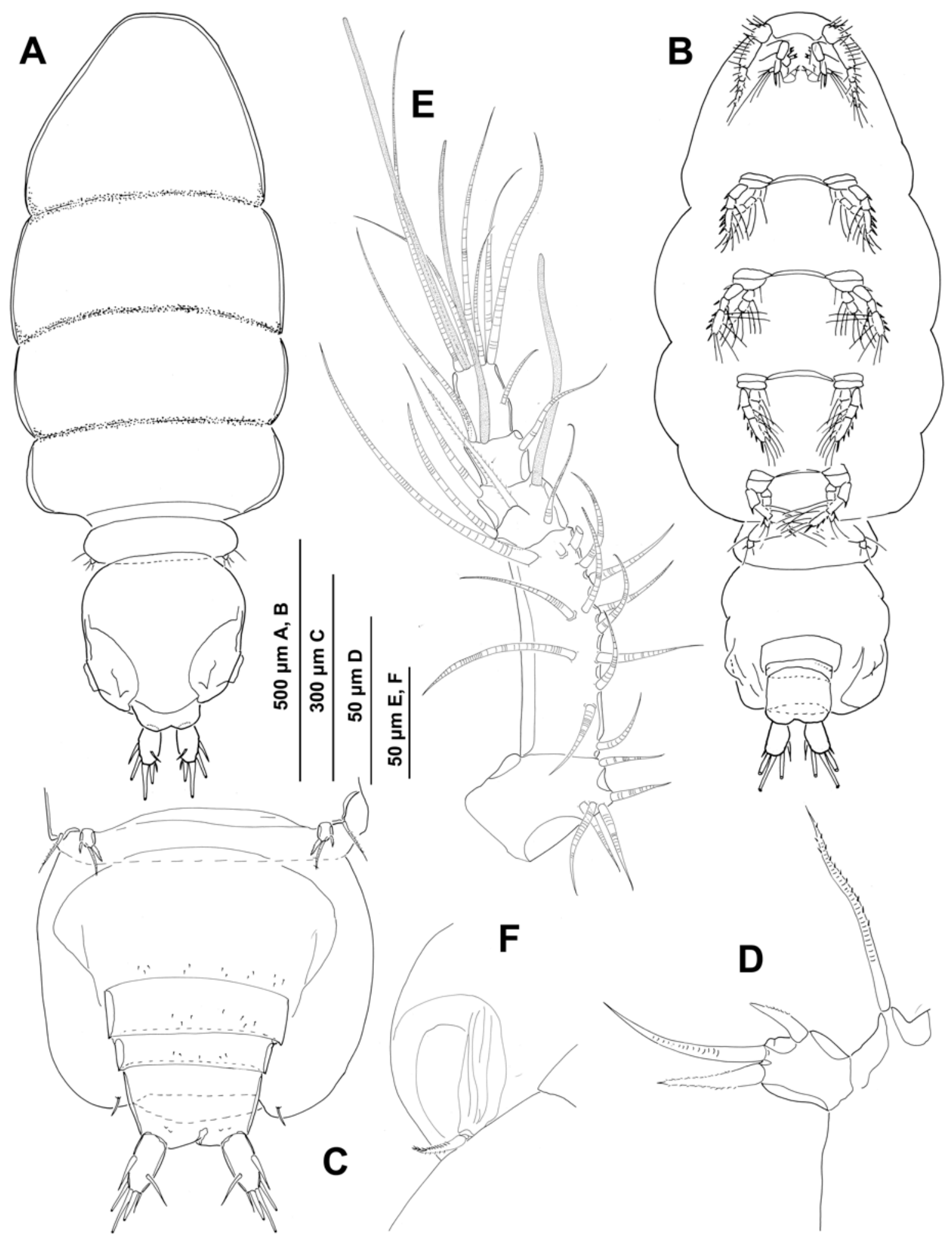

Figure 1. Ophelicola kurambia sp. nov. (female). A, habitus dorsal; B, habitus ventral; C, urosome ventral; D, leg 5; E, antennule; F, genital area. 


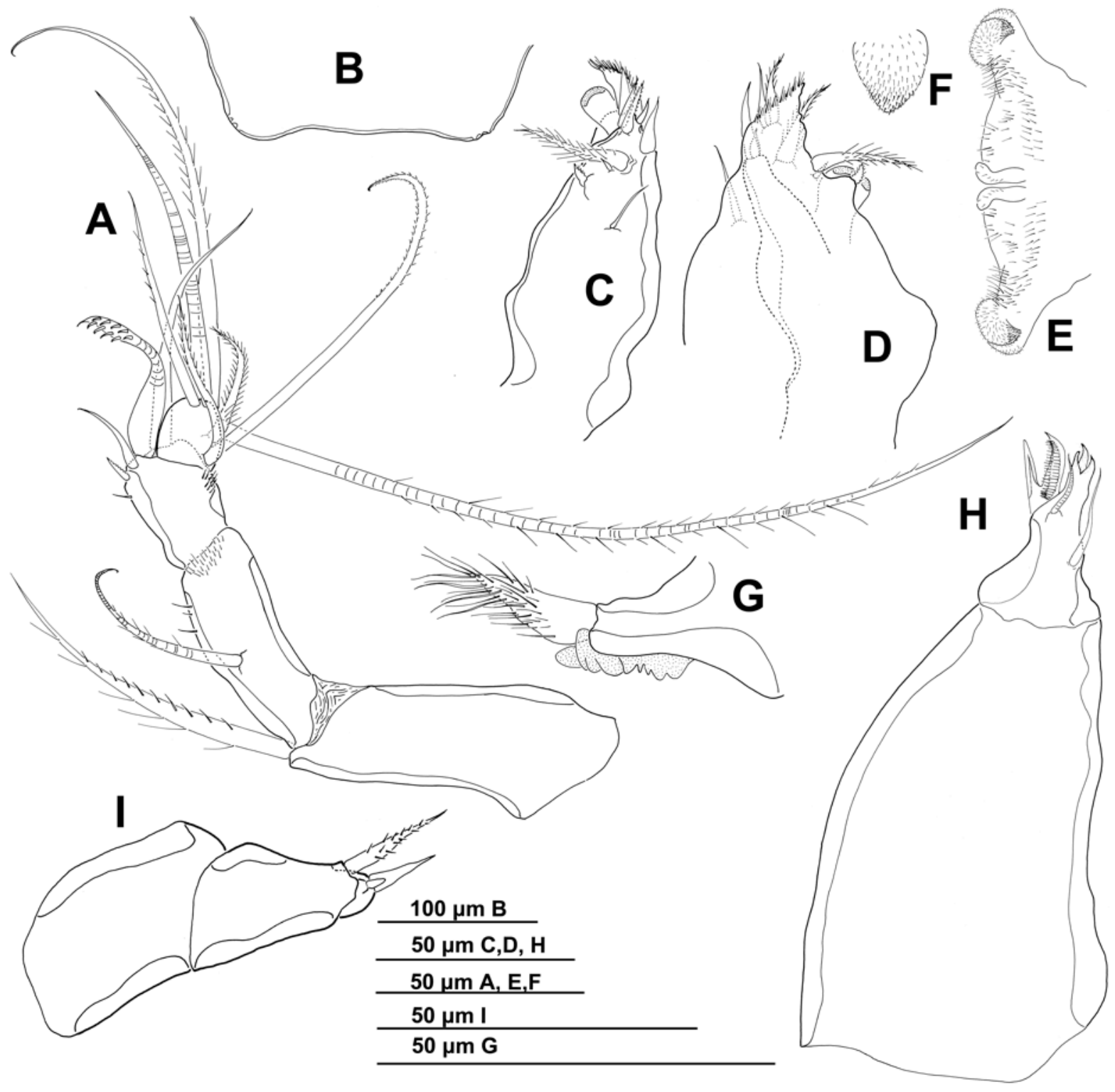

Figure 2. Ophelicola kurambia sp. nov. (female). A, antenna; B, rostrum; C, D, maxillule; E, labrum; F, detail of rounded lobe of labrum; G; mandible; H, maxilla; I, maxilliped. 


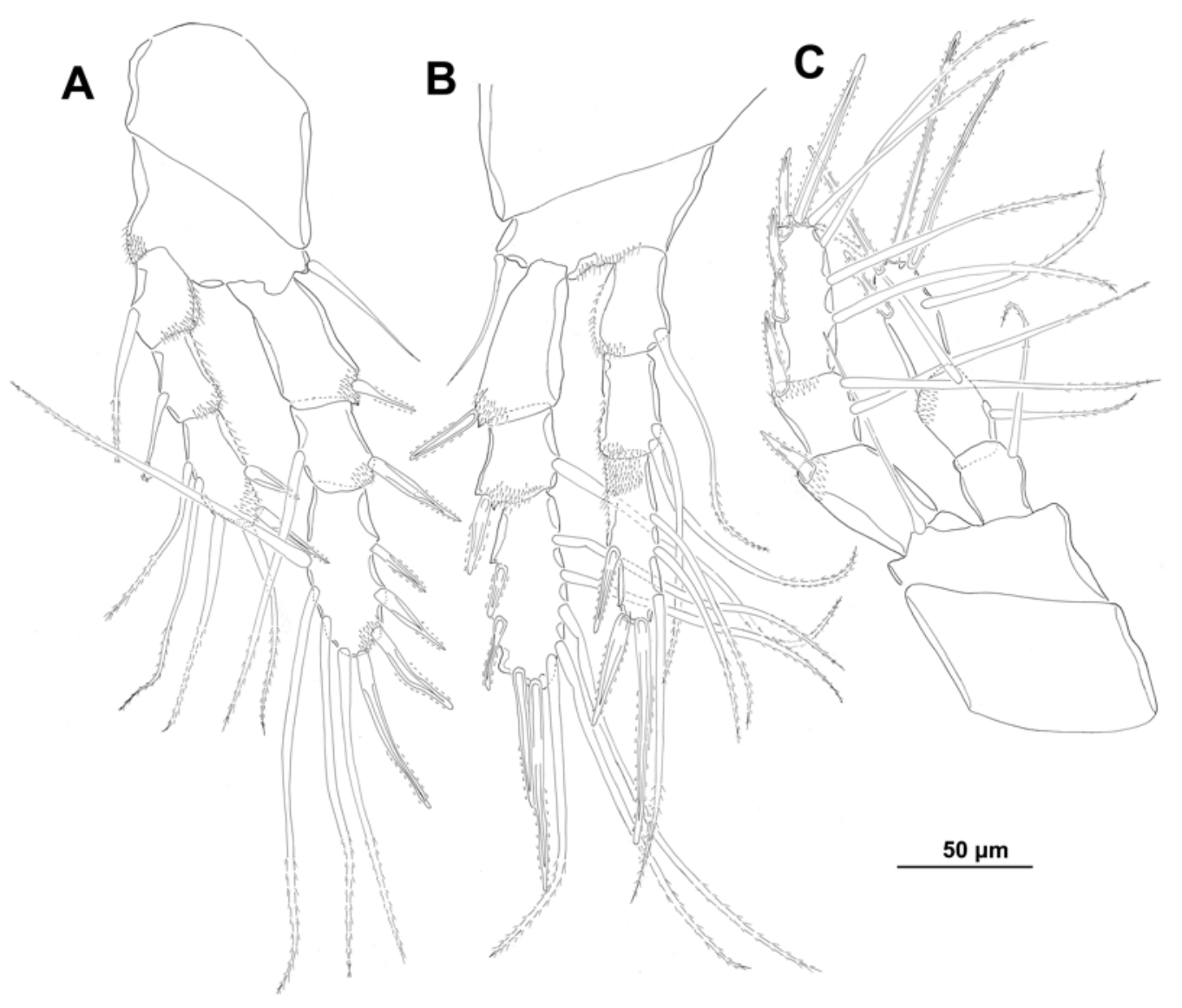

Figure 3. Ophelicola kurambia sp. nov. (female). A, leg 1; B, leg 2; C, leg 4.

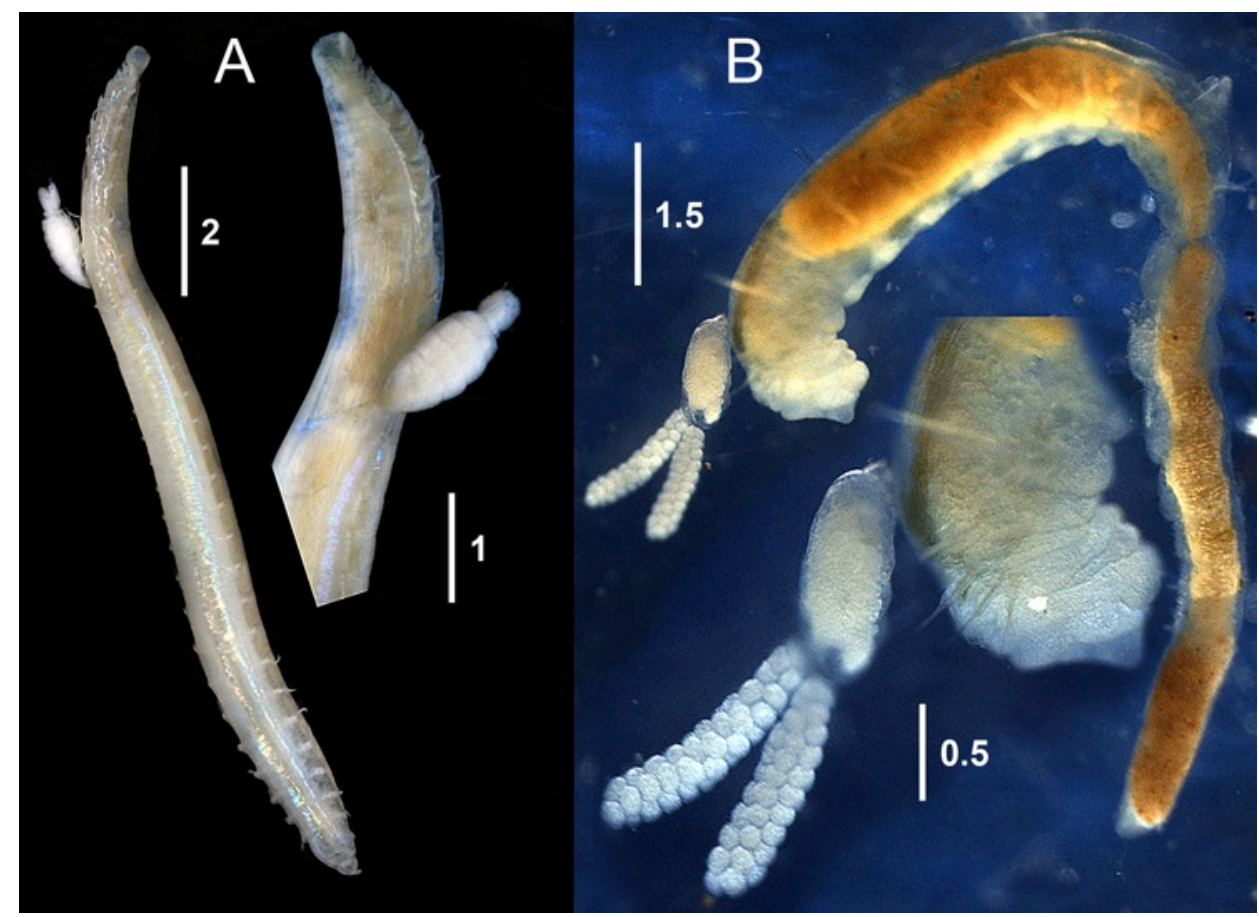

Figure 4. Living specimens of the parasitic copepods attached to their polychaete hosts. a Ophelicola kurambia sp. nov. (female) and its host Opheliidae; b-Anomopsyllus sp. and its host Ampharetidae. 
Table 1.- Genus Ophelicola (redefinition). Armature formula of legs 1 - 4.

\begin{tabular}{lcccc}
\hline & Coxa & Basis & Exopodal segments & Endopodal segments \\
\hline Leg 1 & $0-0$ & $1-0$ & I-0;I-1;III,I,4 & $0-1 ; 0-1 ;$ II,4 \\
Leg 2 & $0-0$ & $1-0$ & I-0;I-1;III,I,5 & $0-1 ; 0-2 ;$ II,4 (I,II,3) \\
Leg 3 & $0-0$ & $1-0$ & I-0;I-1;III,I,5 & $0-1 ; 0-2 ;$ II,4 (I,II,3) \\
Leg 4 & $0-0$ & $1-0$ & I-0;I-1;III,I,5 (4) & $0-1 ; 0-2 ;$ III,2 (I,III,1) \\
\hline
\end{tabular}

Table 2.- Ophelicola kurambia sp. nov. Armature formula of legs $1-4$.

\begin{tabular}{lcccc}
\hline & Coxa & Basis & Exopodal segments & Endopodal segments \\
\hline Leg 1 & $0-0$ & $1-0$ & I-0; I-1, III, I, 4 & $0-1 ; 0-1 ;$ II, 4 \\
Leg 2 & $0-0$ & $1-0$ & I-0; I-1; III, I, 5 & $0-1 ; 0-2 ;$ I, II, 3 \\
Leg 3 & $0-0$ & $1-0$ & I-0; I-1; III, I, 5 & $0-1 ; 0-2 ;$ I, II, 3 \\
Leg 4 & $0-0$ & $1-0$ & I-0; I-2; III, I, 4 & $0-1 ; 0-2 ;$ I, III, 1 \\
\hline
\end{tabular}

Table 3.- Comparison of the armature formula for legs 1-4 according to Laubier (1978), Boxshall and Halsey (2004) and the specimen of Ophelicola kurambia sp. nov.; end: endopodal segment; ex: exopodal segment.

\begin{tabular}{lccc}
\hline & Laubier (1978) & Boxshall \& Halsey (2004) & Ophelicola kurambia sp. nov. \\
\hline Leg 2 end. & $0-1 ; 0-2 ;$ II,4 & $0-1 ; 0-2 ;$ II,4 & $0-1 ; 0-2 ; \mathrm{I}, \mathrm{II}, 3$ \\
Leg 3 ex. & I-0;I-1;II,II,6 & I-0;I-1;III,I,5 & I-0;I-1;III,I,5 \\
Leg 3 end. & $0-1 ; 0-2 ;$ III,3 & $0-1 ; 0-2 ;$ II,4 & $0-1 ; 0-2 ; I, I I, 3$ \\
Leg 4 ex. & I-0;I-1; III,3,3 & I-0;I-1;III,I,5 & I-0;I-2;III,I,4 \\
Leg 4 end. & $0-1 ; 0-2 ;$ III,2 & $0-1 ; 0-2 ;$ III,2 & $0-1 ; 0-2 ;$ I,III,1 \\
\hline
\end{tabular}


Table 4.- List of known annelidicolous copepods (excluding monstrilloids) including the type of association, the polychaete hosts, known depth and geographical ranges of distribution and main references. Gi: Genus inquerendum

\begin{tabular}{|c|c|c|c|c|c|c|c|}
\hline \multicolumn{2}{|c|}{ Anelidicolous Copepods } & \multirow{3}{*}{$\begin{array}{l}\text { Type } \\
\frac{?}{\text { Mesparasite }}\end{array}$} & \multicolumn{2}{|c|}{ Polychaete hosts } & \multirow{2}{*}{$\begin{array}{c}\text { Depth } \\
180-300 \mathrm{~m}\end{array}$} & Distribution & \multirow{2}{*}{$\begin{array}{l}\text { References } \\
\text { Kim et al. (2013) }\end{array}$} \\
\hline Anomoclausiidae & Anomoclaussia indrehussae Gotto, 1964 & & Spionidae & Psendopolydora paucibranch hiata (Okuda, 1937) & & Norway & \\
\hline $\begin{array}{l}\text { Bradophilidae } \\
\text { Bradonhilade }\end{array}$ & 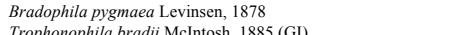 & & Flabelligeridae & Brada villosa (Rathke, 1843) & & White Sea, Groenland & Marchenov (2002) \\
\hline $\begin{array}{l}\text { Bradophilidae } \\
\text { Catiniidae }\end{array}$ & $\begin{array}{l}\text { Trophonophila bradaii Milchtosh, } 11885 \text { (GI) } \\
\text { Cotylemyzon vervoorti Stock, } 1882\end{array}$ & $\stackrel{?}{?}$ Ectoparasite & $\begin{array}{l}\text { Flabelileridae } \\
\text { Acoetidae }\end{array}$ & $\begin{array}{l}\text { lllyphaugus wwvillei (Mclntoshh, 1885) } \\
\text { Eupplyodontes amboinensis Malaquin \& Dehorne, } 1907\end{array}$ & $\begin{array}{l}3,566 \mathrm{~m} \\
40 \mathrm{~m}\end{array}$ & $\begin{array}{l}\text { Antarctic } \\
\text { Indonsia }\end{array}$ & $\begin{array}{l}\text { Boxxhall \& Hasley (2004) } \\
\text { Stock, 1981; Boxshall \& Hasley (2004) }\end{array}$ \\
\hline \multirow{4}{*}{$\begin{array}{l}\text { Clausidididae } \\
\text { Clausididae }\end{array}$} & 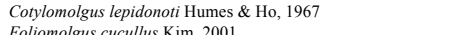 & $\begin{array}{l}\text { Ectoparasite } \\
\text { FEtopasite }\end{array}$ & Unknown & Unknown & & Madagascar & Boxshall \& Hasley (2004) \\
\hline & $\begin{array}{l}\text { Foliomolgus cucullus Kim, 2001 } \\
\text { Hersiliodes latericia (Grube, 1869) }\end{array}$ & $\begin{array}{l}\text { Ectoparasite } \\
\text { Ectoparasite }\end{array}$ & $\begin{array}{l}\text { Eunicidae } \\
\text { Maldanidae }\end{array}$ & $\begin{array}{l}\text { Marphysas sangyinea (Montagu, } 1815) \\
\text { Praxillura longuissima Arwidsson, } 1906\end{array}$ & intertidal & $\begin{array}{l}\text { Korea } \\
\text { Channel and Atlantic coasts of Europe and Mediterranean Sea }\end{array}$ & $\begin{array}{l}\text { Kim (2001b) } \\
\text { O'Reilly (1995) }\end{array}$ \\
\hline & & & Maldanidae & Leiochone leiopygos (Grube, 1860) & & Channel and Atlantic coasts of Europe and Mediterranean Sea & O'Reilly (1995) \\
\hline & & & Maldanidae & Euclymene oerstedii (Claparède, 1863) & & Channel and Atlantic coasts of Europe and Mediterranean Sea & O'Reilly (1995) \\
\hline Clausidididae & Goodingius adhaerens (Williams, 1907) & $?$ & Unknown & Unknown & & & Williams (1907) \\
\hline $\begin{array}{l}\text { Clausidididae } \\
\text { Clavidididec }\end{array}$ & 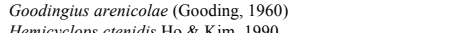 & $\stackrel{?}{?}$ & Arenicolidae & Arenicola cristata Stimpson, 1856 & intertidal & USA (Massachussetts) & Gooding (1960) \\
\hline $\begin{array}{l}\text { Clausidididae } \\
\text { Clausdididae }\end{array}$ & $\begin{array}{l}\text { Hemicyclops ctenidis Ho \& Kim, } 1990 \\
\text { Hemicrllop navusutus Moom \& Kim } 2010\end{array}$ & $\begin{array}{l}\text { Ectoparasite } \\
?\end{array}$ & $\begin{array}{l}\text { Nereididae } \\
\text { Unknown }\end{array}$ & $\begin{array}{l}\text { Neanthes japonica (Izuka, 1908) } \\
\text { Unknown }\end{array}$ & shallow & Korea, Sea of Japan, brackish lagoon & Ho \& $\operatorname{Kim}(1990)$ \\
\hline $\begin{array}{l}\text { Claustldidae } \\
\text { Clausididae }\end{array}$ & 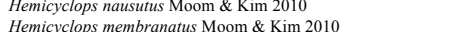 & $?$ & $\begin{array}{l}\text { Unknown } \\
\text { Unknown }\end{array}$ & $\begin{array}{l}\text { Unknown } \\
\text { Unknown }\end{array}$ & & $\begin{array}{l}\text { Korea } \\
\text { Korea }\end{array}$ & $\begin{array}{l}\text { Moom \& Kim (2210) } \\
\text { Moom \& Kim }(2010)\end{array}$ \\
\hline Clausiidae & Claussia lubbockii Claparéde, 1863 & Ectoparasite & Spionidae & Dipolydora sp. & $16 \mathrm{~m}$ & $\begin{array}{l}\text { Korea } \\
\text { Europe }\end{array}$ & $\begin{array}{l}\text { Kim et al. (2013) } \\
\text { (2013) }\end{array}$ \\
\hline & & & Maldanidae & $\begin{array}{l}\text { Unknown } \\
\text { Unkown }\end{array}$ & Fol & Europe & Kim et al. (2013) \\
\hline $\begin{array}{l}\text { Claussinae } \\
\text { Clausidae }\end{array}$ & 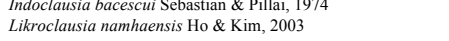 & 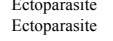 & $\begin{array}{l}\text { Madanidace } \\
\text { Capitellidae }\end{array}$ & $\begin{array}{l}\text { Unknown } \\
\text { Dasybranchus caducus (Grube, 1846) }\end{array}$ & & Kyokpo, Korea, Yellow Sea & $\begin{array}{l}\text { Sebastian \& Pillai (1974) } \\
\text { Ho \& Kim (2003), host as Dasybranchus caudatus? }\end{array}$ \\
\hline \multirow{4}{*}{$\begin{array}{l}\text { Clausidae } \\
\text { Clausiidae }\end{array}$} & Megaclausia mirabilis O'Reilly, 1995 & Commensal & Maldanidae & Rhodine gracilior Tauber, 1879 & & & O'Reilly (1995) \\
\hline & Messilia culthae (T. \& A. Scott, 1986) & 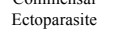 & Spionidae & 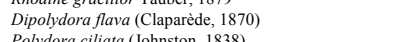 & $\begin{array}{l}70-105 \mathrm{~m} \\
15-105 \mathrm{~m}\end{array}$ & British waters & 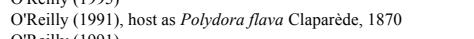 \\
\hline & & & 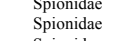 & 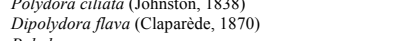 & $\begin{array}{r}15-105 \mathrm{~m} \\
15-105 \mathrm{~m}\end{array}$ & $\begin{array}{l}\text { Britush waters of } \\
\text { Channel coasts of France }\end{array}$ & 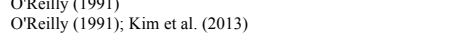 \\
\hline & & & $\begin{array}{c}\text { Spionidae } \\
\text { Arenicolidase }\end{array}$ & Polydora sp. & & British waters & O'Reilly (1991); Kim et al. (2013) \\
\hline $\begin{array}{l}\text { Clausiidae } \\
\text { Clausidaee }\end{array}$ & $\begin{array}{l}\text { Pontocluassia antiqua (Kim, 2000) } \\
\text { Pontoclausia lobata (Kim, 2000) }\end{array}$ & $\begin{array}{l}\text { CEctoparassite } \\
\text { Fctoparasite }\end{array}$ & $\begin{array}{l}\text { Arenicolidae } \\
\text { Eunicidae }\end{array}$ & 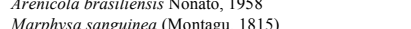 & & $\begin{array}{l}\text { Korea } \\
\text { Yellow }\end{array}$ & Kim (2001b) \\
\hline $\begin{array}{ll}\text { Clausiidae } \\
\text { Clide }\end{array}$ & Pontoclaussia prima (Rocha, 1986) & $\begin{array}{l}\text { 每cloparassite } \\
\text { Ectoparasite }\end{array}$ & $\begin{array}{l}\text { Eunctidae } \\
\text { Unknown }\end{array}$ & 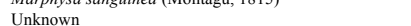 & & Brazi & $\begin{array}{ll}\operatorname{Kim}(2000) \\
\operatorname{Kim}(2001 \mathrm{c})\end{array}$ \\
\hline Clausiidae & Pontoclausia wilsoni (Gooding, 1963) & Ectoparasite & Unknown & Unknown & & & $\operatorname{Kim}(2001 c)$ \\
\hline Clausiidae & Psendoclausia giesbrechti Bocquet \& Stock, 1963 & Ectoparasite & Unknown & Unknown & & France & Bocquet \& Stock (1963) \\
\hline $\begin{array}{l}\text { Clausiidae } \\
\text { Clausidaae }\end{array}$ & 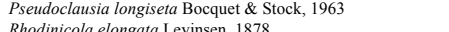 & $\begin{array}{l}\text { Ectoparasitit } \\
\text { Ecctoparasite }\end{array}$ & $\begin{array}{l}\text { Unknown } \\
\text { Maldanidac }\end{array}$ & $\begin{array}{l}\text { Unknown } \\
\text { Phodive }\end{array}$ & & $\begin{array}{l}\text { France } \\
\text { Demenark }\end{array}$ & Bocquet \& Stock (1963) \\
\hline Clausiidae & Rhodinicola elongatata Levinsen, 1878 & Ectoparasite & $\begin{array}{l}\text { Maldanidae } \\
\text { Maldanidae }\end{array}$ & $\begin{array}{l}\text { Rhodine gracicilior Taubere, } 1879 \\
\text { Rhodine loveni Malmgren, } 1865\end{array}$ & & $\begin{array}{l}\text { Demank } \\
\text { British waters }\end{array}$ & 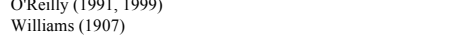 \\
\hline \multirow{5}{*}{$\begin{array}{l}\text { Clausiidae } \\
\text { Clausidaae } \\
\text { Clausiidae }\end{array}$} & Rhodinicola gibbosum Bresciani, 1964 & Ectoparasite & Maldanidac & Praxillella praetermissa (Montagu, 1865) & $74-327 \mathrm{~m}$ & Denmark & Bresciani (1964) \\
\hline & 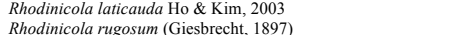 & $\begin{array}{l}\text { Ectoparasite } \\
\text { Ectoparasite }\end{array}$ & $\begin{array}{l}\text { Unknown } \\
\text { Maldaniage }\end{array}$ & $\begin{array}{l}\text { Unknown } \\
\text { Micreclyene tricirrata Arwidsson } 1906\end{array}$ & $104 \mathrm{~m}$ & $\begin{array}{l}\text { Yellow Sea } \\
\text { Central North Sea }\end{array}$ & Ho \& Kim (2003) \\
\hline & & & & & & Central North Sea & $\begin{array}{l}\text { Kim et al. (2013), host as Clymenura tricirrata (Arwidsson, } \\
1900 \text { ) }\end{array}$ \\
\hline & & & $\begin{array}{l}\text { Maldanidae } \\
\text { Maldanidae }\end{array}$ & $\begin{array}{l}\text { Euclymenensp. } \\
\text { Praxillela affinis (Sars in G.O. Sars, 1872) }\end{array}$ & $\begin{array}{ll}104 \mathrm{~m} \\
35 \mathrm{~m}\end{array}$ & $\begin{array}{l}\text { Central North Sea } \\
\text { Engnaland Suffok and East Sussex }\end{array}$ & $\begin{array}{l}\text { Kim et al. (2013) } \\
\text { Kim et ala (2013) }\end{array}$ \\
\hline & & & Maldanidae & Leiochone johnsoni Mclntosh, 1915 & $64 \mathrm{~m}$ & North Sea & Kim et al. (2013), host as Clymenura johnstoni (McIntosh, 1915) \\
\hline Clausiidae & Rhodinicola tennuis Kim, Sikosky, O'Reilly \& Boxhall 2013 & Ectoparasite & Unknown & Unknown & $69 \mathrm{~m}$ & Europe & Kim et al. (2013) \\
\hline Clausiidae & 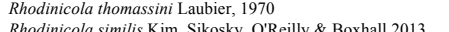 & Ectoparasite & Maldanidae & Leiochone tenuis Day, 1957 & 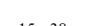 & Tulear Reef, Madagascar & Laubier, (1970, 1971); Ho \& Kim (2003) \\
\hline $\begin{array}{l}\text { Clausiidae } \\
\text { Clausidae }\end{array}$ & 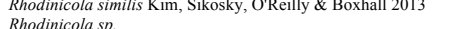 & $\begin{array}{c}\text { Ectoparasiti } \\
\text { Fctronarasite }\end{array}$ & $\begin{array}{l}\text { Maldanidae } \\
\text { Maldaniage }\end{array}$ & 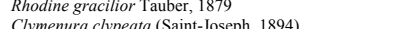 & $15-38 \mathrm{~m}$ & Scotland & Kim et al. (2013) \\
\hline $\begin{array}{l}\text { Claussidace } \\
\text { Clausidae }\end{array}$ & 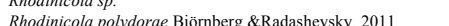 & $\begin{array}{l}\text { Scloparassic } \\
\text { Ectoparasite }\end{array}$ & 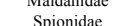 & 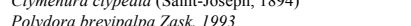 & & Peter the Great Bay Sea of Japan & Pientily \\
\hline 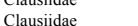 & 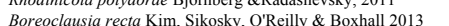 & 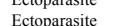 & 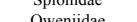 & 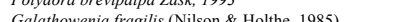 & $350 \mathrm{~m}$ & 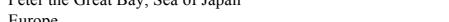 & Bjormberg \& Radashevsky (2011) \\
\hline $\begin{array}{l}\text { Clausiidae } \\
\text { Clase }\end{array}$ & 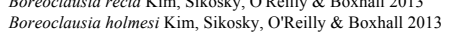 & $\begin{array}{l}\text { Ectoparasite } \\
\text { Ente }\end{array}$ & $\begin{array}{l}\text { Owentidae } \\
\text { Oweniidae }\end{array}$ & 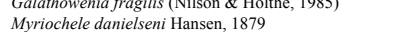 & $11-178 \mathrm{~m}$ & $\begin{array}{l}\text { Europe } \\
\text { Europe }\end{array}$ & $\begin{array}{l}\text { Kime et al. (2013) } \\
\text { Kim et al. (2013) }\end{array}$ \\
\hline Clausiidae & Sheaderia bifida Kim, Sikosky, O'Reilly \& Boxhall 2013 & Ectoparasite & Maldanidae & Euclymene oerstedii (Claparede, 1863) & $146 \mathrm{~m}$ & Europe & Kim et al. (2013) \\
\hline Clausiidae & Vivgottoia garwoodi Kim, Sikosky, O'Reilly \& Boxhall 2013 & Ectoparasite & Terebellidae & Phisidia aurea Southward, 1956 & $32 \mathrm{~m}$ & Europe & Kim et al. (2013) \\
\hline & Hemadona clavicrura Ho \& Kim, 2004 & Ectoparasite & Capitellidae & Dassbranchus caducus (Grube, 1846) & & Namhae-do Island, Korea & Ho \& Kim (2004), host as Dasybranchus caudatus i \\
\hline Clausiidae & Donusa clymenicola von Nordmann, 1864 & Ectoparasite & Maldanidae & Nicomache lumbricalis (Fabricius, 1780) & & Aegean Sea & Chad \& Boxshall (2014), host as Clymene lumbricalis Savigny in \\
\hline \multirow{4}{*}{$\begin{array}{l}\text { Clausiidace } \\
\text { Clausididae } \\
\text { Clausidae } \\
\text { Dirivultidae } \\
\text { Ectinsomatidae } \\
\text { (Harpacticoida) } \\
\text { Entobiidae }\end{array}$} & Flabelliphilus inersus Bresciani \& Lützen, 1962 & Ectoparasite & Flabelligeridae & Flabelligera affinis Sars, 1829 & & Coasts of Sweden & $\begin{array}{l}\text { Lamarkc, 1818 } \\
\text { Chad \& Boxshall (2014) }\end{array}$ \\
\hline & $\begin{array}{l}\text { Jeanenlla sp. } \\
\text { Praxilinicola kroveri McIntosh, } 1885 \text { (GI) }\end{array}$ & $\begin{array}{l}\text { Ectoparasite } \\
?\end{array}$ & $\begin{array}{l}\text { Maldanidae } \\
\text { Maldanidae }\end{array}$ & 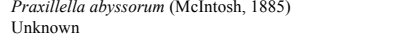 & & British Sea & $\begin{array}{l}\text { Chad \& Boxssall } \\
\text { O'Reilly (1995) }\end{array}$ \\
\hline & 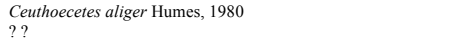 & $\begin{array}{l}\text { Ectoparasite } \\
?\end{array}$ & $\begin{array}{l}\text { Siboglinidae } \\
\text { Serrulidae }\end{array}$ & 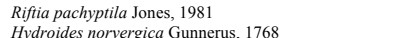 & & $\begin{array}{l}\text { Galapagos Rift \& East Pacific Rise } \\
\text { British waters }\end{array}$ & $\begin{array}{l}\text { Humes \& Doriji (1980) } \\
\text { OReilly (1995) }\end{array}$ \\
\hline & Entobius euelpis Barnard, 1948 & Endoparasite & Terebellidae & Unknown & & Bristish waters; off the South African coast to Red Sea & Dogiel (1908); Barnard (1948); Gotto (1966) \\
\hline Entobiidae & Entobius hamondi Gotto, 1966 & Endoparasite & Terebellidae & Polycirrus caliendrum Claparède, 1869 & $12 \mathrm{~m}$ & Asis shoal, Plymouth & Gotto (1966) \\
\hline Entobiidae & Entobbus Loimiae Dogiel, 1908 & $?$ & Terebellidae & Loimia medusa (Savigny in Lamarck, 1818) & & & Dogiel (1908) \\
\hline Entobiidae & 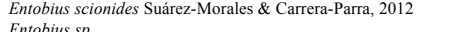 & $\begin{array}{l}\text { Endoparasite } \\
\text { Fndeperasition }\end{array}$ & Terebellidac & Scionides reticulata (Elhers, 1887) & & Gulf of Mexico, Caribbean Sea & 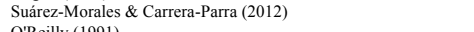 \\
\hline $\begin{array}{l}\text { Entobildae } \\
\text { Entobiidae }\end{array}$ & $\begin{array}{l}\text { Entobiutsp. } \\
\text { Entobius sp. }\end{array}$ & 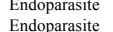 & $\begin{array}{l}\text { Terbeleliliae } \\
\text { Terebllidae }\end{array}$ & $\begin{array}{l}\text { Polycirrus plumosus (wo } \\
\text { Polvcirus medusa Grube, }\end{array}$ & & & $\begin{array}{l}\text { OReily } \\
\text { O'Reily }\end{array}$ \\
\hline $\begin{array}{l}\text { Entonidac } \\
\text { Eunicicolidae }\end{array}$ & Eunicicisolac clausi Kurz, 1877 & $\begin{array}{l}\text { Encoparsite } \\
\text { Ectoparasite }\end{array}$ & $\begin{array}{l}1 \\
\text { Eunicidadade }\end{array}$ & 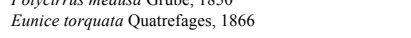 & & Adriatic, Norway, Faroes Island, and British waters & Kim (2005), host as Eunice claparedi Quatrefages, 1866 \\
\hline $\begin{array}{l}\text { Eunicicolidae } \\
\text { Gastrodelphyidae }\end{array}$ & $\begin{array}{l}\text { Eunicicola insolens (T. \& A. Scott, 1913) } \\
\text { Gastrodelphys clausii Graeffe, } 1883\end{array}$ & $\begin{array}{l}\text { Ectoparasite } \\
\text { Ectoparasite }\end{array}$ & $\begin{array}{l}\text { Eunicidade } \\
\text { Sabellidae }\end{array}$ & $\begin{array}{l}\text { Eunice harasssii Andouin \& Milin Edwards, } 1834 \\
\text { Bispira volutacorris (Montagu, 1804) }\end{array}$ & & $\begin{array}{l}\text { north-east coast of Ireland } \\
\text { Envolis Channeland Medierranean }\end{array}$ & $\begin{array}{l}\text { Gotto (1963); Kim (2005) } \\
\text { Boxhall \& Hasley 2004) }\end{array}$ \\
\hline & & & Sabellidae & 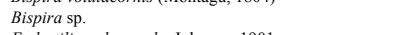 & & Adriatic Sea & Boxshall \& Hasley (2004), host as Distyla josephinae i \\
\hline $\begin{array}{l}\text { Gastrodelphyydiae } \\
\text { Gastrodelphyidae }\end{array}$ & $\begin{array}{l}\text { Gastrodelehhys dalesi (Green, } 18661) \\
\text { Gastrodephys fernaldi Dudley, } 1964\end{array}$ & $\begin{array}{l}\text { 祭toparasite } \\
\text { Ectoparasite }\end{array}$ & $\begin{array}{l}\text { Sabellidae } \\
\text { Sabellidaa }\end{array}$ & $\begin{array}{l}\text { Eudystilia polymmorpha J Johsson, } 1901 \\
\text { Bispira crassicornis (Sars, } 1851 \text { ) }\end{array}$ & & $\begin{array}{l}\text { Californian coast } \\
\text { Pacific coast, USA }\end{array}$ & $\begin{array}{l}\text { Boxshall \& Hasley (2004) } \\
\text { Boxshall \& Hasley (2004) }\end{array}$ \\
\hline & & & $\begin{array}{l}\text { Sabellidae } \\
\text { Sabue }\end{array}$ & $\begin{array}{l}\text { Bispira sp. } \\
\text { s. }\end{array}$ & & Pacific coast, USA & 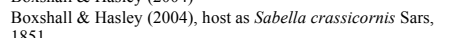 \\
\hline Gastrodelphyidae & Gastrodelphys myxicolae List, 1889 & Ectoparasite & Sabellidae & Myxicola infundibulum (Montagu, 1808) & & Adriatic Sea & $\begin{array}{l}1851 \text { Boll \& Hasley (2004) } \\
\text { Boxshall }\end{array}$ \\
\hline $\begin{array}{l}\text { Gastrodelphyidae } \\
\text { Gastrodelphyidae }\end{array}$ & $\begin{array}{l}\text { Sabellacherese aenigmatopyyus Carton, } 1971 \\
\text { Sabellacheres antarcticus Suarez-Morales \& Boxshal } 2012\end{array}$ & $\begin{array}{l}\text { Ectoparasite } \\
\text { Ectoparasite }\end{array}$ & $\begin{array}{l}\text { Sabellidae } \\
\text { Sabellidae }\end{array}$ & 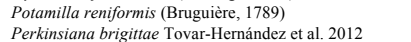 & & $\begin{array}{l}\text { Madagascar } \\
\text { Antarctic }\end{array}$ & $\begin{array}{l}\text { Carton (1971) } \\
\text { Suare-Morale \& Boxshal } 2012)\end{array}$ \\
\hline $\begin{array}{l}\text { Gastrodelphyidae } \\
\text { Gastrodelphyidae }\end{array}$ & $\begin{array}{l}\text { Sabellacheres drachi Laubier, } 1868 \\
\text { Sabellacheres gracilis Sars, } 1862\end{array}$ & $\begin{array}{l}\text { Ectoparasite } \\
\text { Ectoparasite }\end{array}$ & $\begin{array}{l}\text { Sabellidae } \\
\text { Sabellidae }\end{array}$ & $\begin{array}{l}\text { Potamilla thorelli (Malmgren, 1866) } \\
\text { Myxicola infundibulum (Montagu, 1808) }\end{array}$ & & $\begin{array}{l}\text { Spain } \\
\text { Pacific coast, USA }\end{array}$ & $\begin{array}{l}\text { Boxshall \& Hasley (2004) } \\
\text { Boxshall \& Hasley (2004) }\end{array}$ \\
\hline
\end{tabular}




\begin{tabular}{|c|c|c|c|c|c|c|c|}
\hline Gastrodelphyidae & Sabellacheres illgi Dudley, 1964 & Ectoparasite & Sabellidae & Megalomma splendida (Moore, 1905) & & Pacific coast, USA & $\begin{array}{l}\text { Boxshall \& Hasley (2004), host as Branchiomma burrardum } \\
\text { Berkeley, 1930 }\end{array}$ \\
\hline & & & $\begin{array}{l}\text { Sabellidae } \\
\text { Sabllide }\end{array}$ & Parasabellla rugossa (Moore, 1904) & & Pacific coast, USA & $\begin{array}{l}\text { Dexshall \& Hasley (2004), host as Distylidia rugossa Moore, } 1904 \\
\text { Bot }\end{array}$ \\
\hline Gastrodelphyidae & & Ectoparasite & $\begin{array}{l}\text { Sabellldae } \\
\text { Sabellidae }\end{array}$ & 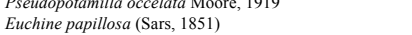 & & $\begin{array}{l}\text { Pactifc coast, USA } \\
\text { North Sea, Norway }\end{array}$ & $\begin{array}{l}\text { Boxxhall \& Hasley (20004) hostas as Potamilila accelatata } \\
\text { G. O. Sars (1870); Sars (1862): Dudley (1964) }\end{array}$ \\
\hline Herpyllobiidae & Eurysilenium fungosum Stock, 1996 & Mesoparasite & Polynoidae & Hemilipidia vershuysi (Horst, 1915) & & Iles Kai, Indonesia & 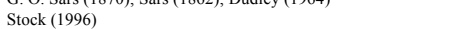 \\
\hline Herpyllobiidae & Eurysilenium intermedium Stock, 1996 & Mesoparasite & Polynoidae & Harmothoe corralophila (Day, 1960) & & New Caledonia & Stock (1986), host as Harmothoe corralophila Day, 1960 \\
\hline Herpyllobiidae & Eurysilenium oblongum Hansen, 1886 & Mesoparasite & 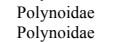 & $\begin{array}{l}\text { Bylgides promamme (Malmgren, 1867) } \\
\text { Harmothoe imbricata (Linnaeus, 1767) }\end{array}$ & & $\begin{array}{l}\text { North Atlantic Ocean } \\
\text { North }\end{array}$ & $\begin{array}{l}\text { Corddl (2007) } \\
\text { Cordel (120077) }\end{array}$ \\
\hline Herpyllobiidae & Eurysilenium truncatum Sars, 1870 & Mesoparasite & Polynoidae & Gattyana cirrhosa (Pallas, 1766) & & North Atlantic Cocan & $\begin{array}{l}\text { Cordel (2007) } \\
\text { Condely }\end{array}$ \\
\hline $\begin{array}{l}\text { Herpyllobiidae } \\
\text { Herpyllobiidae }\end{array}$ & $\begin{array}{l}\text { Eurysilenium australis López-Gonzalez, Bresciani \& Conradi, } 2006 \\
\text { Herpyllobius antarcticus Vanhoffen, } 1913\end{array}$ & $\begin{array}{l}\text { Mesoparasite } \\
\text { Mesoparasite }\end{array}$ & $\begin{array}{l}\text { Polynoidae } \\
\text { Polynoidae } \\
\text { Polynoidae }\end{array}$ & $\begin{array}{l}\text { Harmothoe imbricata (Linnaeus, 1776) } \\
\text { Polveuno as } \\
\text { Polyeunoa laevis } \underline{\underline{M c l n t o s h}, 1885}\end{array}$ & $190-286 \mathrm{~m}$ & $\begin{array}{l}\text { North Atlantic Ocean } \\
\text { Antarctic }\end{array}$ & $\begin{array}{l}\text { Cordell (2007) } \\
\text { Lobez-Gonzalez et al. (2006) } \\
\text { Lopez-Gonzalez et al. (2006), host as Enipo rhombigera Elhers, } \\
\text { 1009 }\end{array}$ \\
\hline & & & Polynoidae & Harmothoe fillo (Grube, 1878) & & & $\begin{array}{l}\text { 19y8 -Gonzalez et al. (2006), host as Harmothoe gourdoni } \\
\text { Lopaz- } 1911\end{array}$ \\
\hline & & & $\begin{array}{c}\text { Polynoidae } \\
\text { Polynoidae }\end{array}$ & $\begin{array}{l}\text { Harmothoe gourdoni Gravier } 1911 \\
\text { Harmothoe spinosa Kinberg, } 1856\end{array}$ & $380 \mathrm{~m}$ & $\begin{array}{l}\text { Antarctic } \\
\text { Antarctic }\end{array}$ & $\begin{array}{l}\text { Lopez-Gonzalez et al. (2006) } \\
\text { López-GGonzalez ex tal. (2006) }\end{array}$ \\
\hline $\begin{array}{l}\text { Herpyllobiidae } \\
\text { Herpyllobiidae }\end{array}$ & $\begin{array}{l}\text { Herpyllobius antepositus Stock, } 1986 \\
\text { Herpyllobius arcticus Steenstrup \& Lütkn, } 1861\end{array}$ & $\begin{array}{l}\text { Mesoparasite } \\
\text { Mesoparasite }\end{array}$ & $\begin{array}{l}\begin{array}{l}\text { Polynoidae } \\
\text { Polynoidae }\end{array} \\
\text { Pan }\end{array}$ & $\begin{array}{l}\text { Lagisca irritans Marenzeller, } 1904 \\
\text { Austrolaenilla mollis (Sars, } 1872 \text { ) }\end{array}$ & $365-485 \mathrm{~m}$ & $\begin{array}{l}\text { Crozet Island } \\
\text { south-west nngland; skagerrak; Faroes; Kattegat; south Norway; east and west } \\
\text { Greenland; Kara Sea }\end{array}$ & $\begin{array}{l}\text { Stock (1986); López-González et al. (2006) } \\
\text { Chad \& Boxshall (2014) }\end{array}$ \\
\hline & & & Polynoidae & Gattyana cirrhosa (Pallas, 1766) & & & O'Reilly (1991) \\
\hline & & & $\begin{array}{c}\text { Polynoidae } \\
\text { P.lvnidae }\end{array}$ & $\begin{array}{l}\text { Harmothoo extenuatata (Grube, 1844) } \\
\text { Harmothoe imbricata (Linnaus, 1776) }\end{array}$ & & & \\
\hline & & & $\begin{array}{l}\text { Polnnoidae } \\
\text { Phyllodocidae }\end{array}$ & $\begin{array}{l}\text { Harmorthe imbricata (Linnaues, 11776) } \\
\text { Eumida sangunina (Oersted, 1843) }\end{array}$ & & & 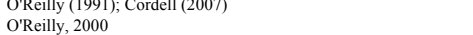 \\
\hline & & & $\begin{array}{l}\text { Phyluodocidae } \\
\text { Polyonida }\end{array}$ & 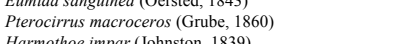 & & & $\begin{array}{l}\text { OReilly, } 2000 \\
\text { O'Reill, }\end{array}$ \\
\hline & & & 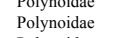 & 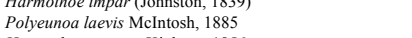 & $666-673 \mathrm{~m}$ & Antarctic & $\begin{array}{l}\text { López-Gonzalez et al. (2006) } \\
\text { Loples }\end{array}$ \\
\hline Herpyllobiidae & Herpyllobius ausstralis Lützen, 1964 & Mesoparasite & Polynoidae & Harmothoe spinosa Kinberg, 1856 & & & Lützen, 1964 \\
\hline $\begin{array}{l}\text { Herpylllobiidae } \\
\text { Herpyllobiidae }\end{array}$ & 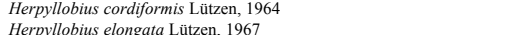 & Mesoparasite & Polynoidae & Eunoe nodosa (Sars, 1861) & & East America, Inglefield Bay, Greenland & Lützen, 1964 \\
\hline & & Mesoparasaste & Polynoidae & Grubeopolynoe tuta (Grube, 1855) & & Southern Bristish, Columbia \& Northern Washington & Lützen, 1967, host as Hololepidella tuta (Grube, 1855) \\
\hline $\begin{array}{l}\text { Herpylllobiidae } \\
\text { Herpyllobidae }\end{array}$ & 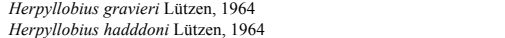 & $\begin{array}{l}\text { Mesoparasitit } \\
\text { Mesoparasite }\end{array}$ & 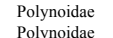 & $\begin{array}{l}\text { Harmothoe spinosa Kinberg, } 1856 \\
\text { Harmotheo imbricatat Limnaeus } 1776\end{array}$ & $380 \mathrm{~m}$ & Antarctic & López-Gonzzalez et al. (2006) \\
\hline Herpyllobiidae & Herpyllobius hartmanae Lütren \& Jones, 1976 & $\begin{array}{l}\text { Mesoparasasite } \\
\text { Meste }\end{array}$ & $\begin{array}{l}\text { Polynoidae } \\
\text { Polyou }\end{array}$ & Laetmonice productata (Grube, 1876$)$ & $476-496 \mathrm{~m}$ & Antarctic & $\begin{array}{l}\text { Lüzzen, } 1964 ; \text {; Cordedel( (2007) } \\
\text { López-Gonzalez et al (2006) }\end{array}$ \\
\hline Herpyllobiidae & Herpyllobius lobosaccus Stock, 1986 & Mesoparasite & Polynoidae & Lagisca irritans Marenzeller, 1904 & $365-485 \mathrm{~m}$ & $\begin{array}{l}\text { Anarecticland } \\
\text { Crozet Island }\end{array}$ & 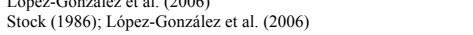 \\
\hline $\begin{array}{l}\text { Herpylllobiidae } \\
\text { Heryllobidaa }\end{array}$ & 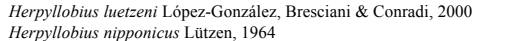 & $\begin{array}{l}\text { Mesoparasitit } \\
\text { Mesoparasite }\end{array}$ & 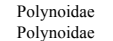 & 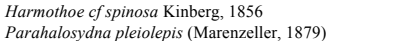 & $93-94 \mathrm{~m}$ & $\begin{array}{l}\text { Antarctic } \\
\text { East America, Kara sea, Greenland, Faroes Isles, Noway, England }\end{array}$ & $\begin{array}{l}\text { Lopez-Gonzzalez et al. (2000) } \\
\text { Lütren, } 1964\end{array}$ \\
\hline $\begin{array}{l}\text { Herpyllobiidae } \\
\text { Herpyllobiidae }\end{array}$ & $\begin{array}{l}\text { Herpyllobius polasterni Ĺ́pez-González, Bresciani \& Conradi, } 2000 \\
\text { Herpyllobius polynoes (Kroyer, 1863) }\end{array}$ & $\begin{array}{l}\text { Mesopparasite } \\
\text { Mesoparasite }\end{array}$ & $\begin{array}{l}\begin{array}{l}\text { Polynoidae } \\
\text { Polynoidae }\end{array} \\
\text { P }\end{array}$ & $\begin{array}{l}\text { Eulagisca gigantea Monro, } 1939 \\
\text { Austrolaenilla mollis (Sars, } 1878 \text { ) }\end{array}$ & $391-673 \mathrm{~m}$ & 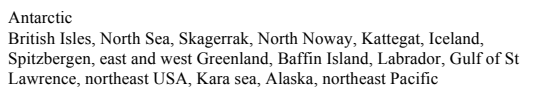 & $\begin{array}{l}\text { López-Gonzáleze et al. (2006) } \\
\text { O'Reilly (1991), Chad \& Boxshall (2014) }\end{array}$ \\
\hline & & & Polynoidae & Bylgides promamme (Malmgren, 1867) & & European waters & Lützen (1964), host as Anthinoe badia (Théel, 1879) \\
\hline & & & $\begin{array}{l}\text { Polynoidae } \\
\text { Polynidace }\end{array}$ & Bylgides sarrsi (Kinberg in Malmgren, 1866) & & $\begin{array}{l}\text { European waters } \\
\text { Eureann waters }\end{array}$ & Lützen (1964) \\
\hline & & & $\begin{array}{l}\text { Polynoidae } \\
\text { Polynoidae }\end{array}$ & $\begin{array}{l}\text { Eunoe enodosas (Sars, 1861) } \\
\text { Gattyana a mnodseni (Malmgren, 1867) }\end{array}$ & & $\begin{array}{l}\text { European waters } \\
\text { European waters }\end{array}$ & $\begin{array}{l}\text { Lützen (1964) } \\
\text { Lüzzen (1964) }\end{array}$ \\
\hline & & & Polynoidae & $\begin{array}{l}\text { Gattyana cirrhosa ( Pallas, 1766) } \\
\text { Ger) }\end{array}$ & & $\begin{array}{l}\text { Europeand waters } \\
\text { Scotland }\end{array}$ & $\begin{array}{l}\text { Lüzzen (1964) } \\
\text { Lutren): O'Reilly (O'Reilly, 1999) }\end{array}$ \\
\hline & & & Polynoidae & Gaudichaudius iphionellioides (Johnson, 1901) & & European waters & 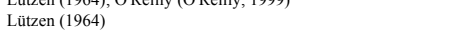 \\
\hline & & & Polynoidae & Harmothoe aspera (Hansen, 1878) & & European waters & Lützen (1964) \\
\hline & & & $\begin{array}{l}\text { Polynoidae } \\
\text { Polynoidae }\end{array}$ & 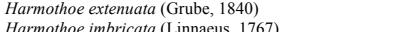 & & $\begin{array}{l}\text { European waters } \\
\text { Furopean waters }\end{array}$ & Lützen (1964) \\
\hline & & & $\begin{array}{l}\text { Polynoidae } \\
\text { Polynoidae }\end{array}$ & $\begin{array}{l}\text { Harmothoe imbricacata(Linnaeass, 17667) } \\
\text { Harmothoe impar (Johnston, 18399) }\end{array}$ & & $\begin{array}{l}\text { European waters } \\
\text { European waters }\end{array}$ & $\begin{array}{l}\text { Lützen (1964); Cordell (2007) } \\
\text { Lürzen 11644) }\end{array}$ \\
\hline & & & 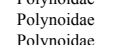 & $\begin{array}{l}\text { Harmohoco impar (Johnston, } 1839 \text { ) } \\
\text { Malmgreniella lunulatat (Delle Chiaje, 1830) }\end{array}$ & & $\begin{array}{l}\text { European waters } \\
\text { British waters } \\
\text { British waters }\end{array}$ & $\begin{array}{l}\text { Luzen (196) } \\
\text { OReilly (1991) }\end{array}$ \\
\hline Herpyllobiidae & Herpyllobius rotundus Lützen \& Jones, 1976 & Mesoparasite & $\begin{array}{l}\text { Polynoidae } \\
\text { Polynoidae }\end{array}$ & $\begin{array}{l}\text { Malmmreneia andreapolis Mclntosh, } 1874 \\
\text { Harmothoe sp. }\end{array}$ & $640-658 \mathrm{~m}$ & $\begin{array}{l}\text { British waters } \\
\text { Cook Strait }\end{array}$ & $\begin{array}{l}\text { ORéilly (1991) } \\
\text { López-Gonzalez et al. (2006) }\end{array}$ \\
\hline Herpyllobiiidae & Herpyllobius stocki López-González, Bresciani \& Conradi, 2000 & Mesoparasite & Polynoidae & Austrolaenilla antarctica Bergström, 1916 & $395-417 \mathrm{~m}$ & Antarctic & López-González et al. (2006) \\
\hline $\begin{array}{l}\text { Herpyllobiidae } \\
\text { Herpyllobiidae }\end{array}$ & 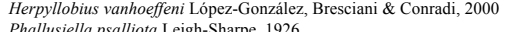 & $\begin{array}{l}\text { Mesoparasite } \\
\text { Mesomarasite }\end{array}$ & $\begin{array}{l}\text { Polynoidae } \\
\text { Polynidae }\end{array}$ & Eulagisca corrientis Mclntosh, 1885 & $666-673 \mathrm{~m}$ & Antarctic & López-Gonzalez et al. (2006) \\
\hline $\begin{array}{l}\text { Herpyylobinae } \\
\text { Herpyllobiidae }\end{array}$ & 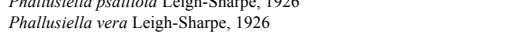 & $\begin{array}{l}\text { Mesoparasste } \\
\text { Mesoparasite }\end{array}$ & $\begin{array}{l}\text { Poynocace } \\
\text { Polynoidae }\end{array}$ & 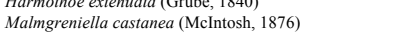 & & Southwest England & O'Reilly (1991), host as Malmgrenia castanea McIntosh, 1876 \\
\hline $\begin{array}{l}\text { Herpyllobiidae } \\
\text { Herpyllobiidae } \\
\text { Herpyllobiidae }\end{array}$ & $\begin{array}{l}\text { Gottoniella antarctica López-Gonzalez, Bresciani \& Conradi, } 2006 \\
\text { Gottoniella andeepi Lopez-Gonzalez, Bresciani \& Conradi, } 2006 \\
\text { Thylacoides sarsis Lravier, } 1912\end{array}$ & $?$ & $\begin{array}{l}\text { Polynoidae } \\
\text { Polynoidae } \\
\text { Syllidae }\end{array}$ & $\begin{array}{l}\text { Unknown } \\
\text { Unknown } \\
\text { Unknown }\end{array}$ & $\begin{array}{c}374-597 \mathrm{~m} \\
2,895 \mathrm{~m}\end{array}$ & $\begin{array}{l}\text { Antarcecic } \\
\text { Antarctic } \\
\text { Antarctic }\end{array}$ & 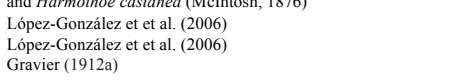 \\
\hline $\begin{array}{l}\text { Miraciidae } \\
\text { (Harpacticoida) }\end{array}$ & Bulbamphiascus imus (Brady, 1872) & Commensal & Capitellidae & Capitella sp. & & Irvine Bay, Scottand & $\begin{array}{l}\text { Moore \& O'Reilly (1993), host as Capitella capitata (Fabricius, } \\
1770 \text { ) }\end{array}$ \\
\hline Nereicolidae & Anomopsyllus abyssorum Laubier, 1968 & Ectoparasite & Ampharetidae & Unkn & $3,992 \mathrm{~m}$ & Gulf of Gascogne & Laubier (1988) \\
\hline $\begin{array}{l}\text { Nereicolidae } \\
\text { Nereciclidece }\end{array}$ & 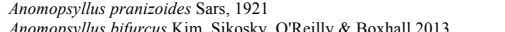 & $\begin{array}{l}\text { Ectoparasite } \\
\text { Fctoparaise }\end{array}$ & $\begin{array}{l}\text { Ampharetidae } \\
\text { Canitillidac }\end{array}$ & Amphi & $300 \mathrm{~m}$ & $\begin{array}{l}\text { Nor } \\
\text { Nor }\end{array}$ & 88) \\
\hline $\begin{array}{l}\text { Nerecichldae } \\
\text { Nereicolidae }\end{array}$ & 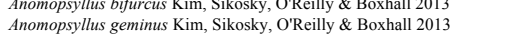 & $\begin{array}{l}\text { Ectoparaste } \\
\text { Ectoparasite }\end{array}$ & $\begin{array}{l}\text { Capptillidiac } \\
\text { Ampharetidae }\end{array}$ & $\begin{array}{l}\text { Notomassust statericius Sarss, } 18 \text {. } \\
\text { Ampharete lindstromi Malmg }\end{array}$ & $\begin{array}{c}105 \mathrm{~m} \\
45-112 \mathrm{~m}\end{array}$ & $\begin{array}{l}\text { Norwwy } \\
\text { Norway }\end{array}$ & \\
\hline Nereicolidae & 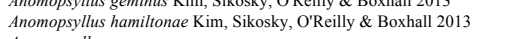 & Ectoparasite & Ampharetidae & Sosane wahrbergi (Eliasson, 1955) & $290 \mathrm{~m}$ & $\begin{array}{l}\text { Northy } \\
\text { Nora, Norway }\end{array}$ & Kim et al. (2013) \\
\hline $\begin{array}{l}\begin{array}{l}\text { Neriecolidae } \\
\text { Nereicolidae }\end{array} \\
\text {. }\end{array}$ & 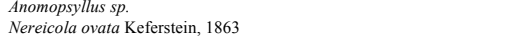 & $\begin{array}{l}\text { Ectoparasite } \\
\text { Ectoparasite }\end{array}$ & $\begin{array}{c}\text { Ampharedidae } \\
\text { Nereididae }\end{array}$ & $\begin{array}{l}\text { Unknown } \\
\text { Nereis elitoralis Eliason, } 1962\end{array}$ & & $\begin{array}{l}\text { Kurile Kambchatkk Trench and absysas plain } \\
\text { English Channel, Mediterranean and Black Seas }\end{array}$ & $\begin{array}{l}\text { This paper } \\
\text { Dantan (1929); Laubier (1965); O'Reilly (1995) }\end{array}$ \\
\hline & & & & Nereis rava Ehlers, 1864 & & Northsouth Atlanthic, North Pacific, Antarctic & Boxshall \& Hasley \\
\hline & & & $\begin{array}{l}\begin{array}{l}\text { Nereididae } \\
\text { Neredidaa }\end{array} \\
\text {. }\end{array}$ & $\begin{array}{l}\text { Nereis zonatat Malmgren, } 1867 \\
\text { Perinereis cultrifera (Grube, 1840) }\end{array}$ & & North Sea, Norway & $\begin{array}{l}\text { Boxshall \& Hasley (2004) } \\
\text { Boxshall \& Hasley (2004) }\end{array}$ \\
\hline & Irticaudatum Wils & & $\begin{array}{c}\text { Nereididae } \\
\text { Unknown }\end{array}$ & $\begin{array}{l}\text { Platynereis dumerilii (Audouin \& Milne Edwards, 1834) } \\
\text { Unnkown }\end{array}$ & & Tortugas Islands, Gulf of Mexico & $\begin{array}{l}\text { Boxshall \& Hasley (2004) } \\
\text { WXison (2023) }\end{array}$ \\
\hline Nereicolidae & 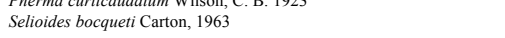 & Ectoparasite & 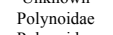 & $\begin{array}{l}\text { Ondnhown } \\
\text { Adyte assimilis (McIntosh, 1874) }\end{array}$ & & Tortugas Islanas, Guir or Mexico & $\begin{array}{l}\text { Buxshall \& Hasley (2004), host as Subadyte assimilis? } \\
\text { Bost }\end{array}$ \\
\hline & & & $\begin{array}{l}\text { Polynoidac } \\
\text { Polynoidae }\end{array}$ & 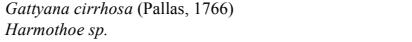 & & $\begin{array}{l}\text { Swedish and d ritish coasts } \\
\text { British waters }\end{array}$ & $\begin{array}{l}\text { O'Reilly (1995) } \\
\text { O'Reilly (1995) }\end{array}$ \\
\hline & & & Polynoidae & Malmgreniella castanea (McIntosh, 1876) & & British waters & O'Reilly (1995) \\
\hline
\end{tabular}


$$
\text { Ecto }
$$ \\ Ectoparasite
Ectoparasite
EEtoparaste
Ectoparasite
Ectoparasite
Ectoparasite
EEtoparasite
Ectoparasite
Ectoparasite
Ectoparasite
EEtoparasite
Ectoparasite
Ectoparasite
Ectoparasite}

$\begin{array}{ll}\text { Polynoidae } & \text { Bylgides sarsi (Kinberg in Malmgren, 1866) } \\ \text { Polynoidae } & \text { Eunoe nodosa (Sars, 1866) }\end{array}$

$\begin{array}{ll}\text { Polynoidae } & \text { Eunoe nodosa (Sars, 1861) } \\ \text { Polynoidae } & \text { Gattyana cirrhosa (Pallas, 1766) }\end{array}$

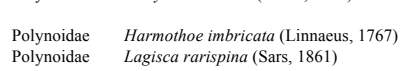

Selioides bullifier Stock, 1986
Selioides capensis Stock, 1986

Selioides guineensis Carton \& Laubier, 1974
Selioides tardus Gravier, 1912

Sigecheres concina (T. Tseott, 1902$)$
Vectoriella marinovi Stock, 1968

Vectoriella ramosae Laubier \& Carton, 1973
Vectoriella gabesensis Kim, Sikosky, O'Reilly \& Boxhall, 2013

Octophiophora lacertae Stock, 1988

Spiranthessius pleurrocephalus Stock, 1995
Psendanthessius tortuosus Stock, Humes \& Gooding, 1964 .

Pseudanthessidiae
Pseudanthessidae

Pseudanthessius gracilis Claus, 1889

$\begin{array}{ll}\text { Pseudanthessiidae } & \begin{array}{l}\text { Pseuddanthessius aestheticus Stock, Humes \& Gooding, } 1964 \\ \text { Pseudanthessidae }\end{array} \\ \text { Pseudanthessius ferox Humes \& Ho, } 1967\end{array}$

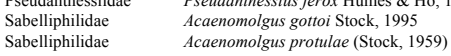

$\begin{array}{ll}\text { Sabelliphilidae } & \text { Acaenomolgus serpulae (Stock, 1960) } \\ \text { Sabelliphilidae } & \text { Dordicicol hirsutites (T. Soct, 1893) } \\ \text { Sabelliphilidae } & \text { Doridicola agilis Leydig, 1853 }\end{array}$

Sabelliphililace
Sabelliphildae
Sald

Sabelliphilidae
Sabellilhhilidae
Sabelliphilidae

Sabelliphilidae
Sabelliphilidae

Sabelliphilidae
Sabelliphilidae

Sabelliphilidac
Sabelliphilidac
Sol

Sabelliphilidac

Sabelliphilidae

Sabelliphilidae
Sabelliphilidae

Sabelliphilidaae
Sabelliphilidae

Sabelliphilidae
Saccopsidae
Saccopsidae

Saccopsidae
Saccopsidae

Saccopsidae
Sapprinidae

Serpulidicoloda

Serpulidicolodac
Serpulidicolodac
Serpulidicolodae

Serpulidicolodae
Serpulidicolodae

Serpulidicolodae
Serpulidicolodae
Doridicola agilis Leydig, 1853
Eupolymniphilus finmarchicus (Scott, 1903)
Myxomolgoides mauritans Humes, 1975

Myxomolgoides mauritanus Humes, 19
Myxomolgus invul gus Kim, 2001

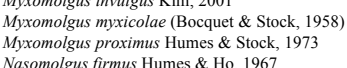

Nasomologus leptus Humes \& Ho, 1967
Nasomolgus parvulus Humes \& Ho, 1967

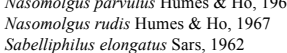

Sabelliphilus elonganus Sars, 1962

Sabelliphilus sarsi Claparède, 1870

Sabelliphilus bispirae McIntosh, 1904 (GI) Serpuliphilus duplus Humes \& Stock, 1973
Serpuliphilus tenax Humes \& Stock, 1973

Terebelliphilus simpex Kim, 2001

Melinnacheres ergasiloides Sars, 1870
Melinnacheres levinseni (McIntosh, 1885)

Melinnacheres tereebelidisis (Levinsen, 1878)
Melinnacheres steenstrupi (Bresciani \& Lütren, 1961)

Flabellicola neapolitana Gravier, 1918 (GI)

Terebellicola reptans Sars, 1862
Parangium abstrusum Humes, 1985

Rhabdopus salmacinae Southward, 1964
Rhynchopus catinatus Stock, 1979

Serpulididic cata jospephellae Humes \& Grassle, 1979
Serpulidicola omphalopomae Southward, 1964

Serpulidicola placostegi Southward, 1964
Serpulidicola segmentatus Stock, 1989 $\begin{array}{ll}\text { Polynoidace } & \text { Gorgoniapolynoe corralophila (Day, } 1960 \\ \text { Polynoidae } & \text { Subbadyle pellucida (Ehlers, 1864) }\end{array}$

$\begin{aligned} & \text { Polynoidae } \\ & \text { Polynoidae }\end{aligned}$ Subadytesp.
Antarctinoe ferox (Baird, 1865)

$\begin{array}{ccc}\text { coparasite } & \text { Polynoidae } & \text { Lepidonotus squamatus (Linnaeus, 1758) } \\ \text { Phyllodocidae } & \text { Eulalia viridis Malmgren, 1865 }\end{array}$

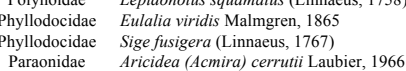

$\begin{array}{ll}\begin{array}{l}\text { Paraonidae } \\ \text { Paraonidae }\end{array} & \begin{array}{l}\text { Aelicira mediterranea Laubier \& Ramos, } 1974 \\ \text { Aricidea catherinae Laubier, } 1967\end{array}\end{array}$

$\begin{array}{cl}\text { Unknown } & \text { Unknown } \\ \text { Sigalionidae } & \text { Sthenolepis areolata (McIntosh, 1885) }\end{array}$

\begin{tabular}{cl}
$\begin{array}{cl}\text { Serpulidae } \\
\text { Phyllodocidae }\end{array}$ & Enknown \\
\hline Eula expusilla Plejiel, 1987
\end{tabular}

Phyllodocidaa
Phyllodocidae

Phyllodocidae Phyllodoce sp.

$\begin{array}{ll}\text { Phyllodocidae } & \text { Phyllodoce rosea (McIntosh, 1877) } \\ \text { Phyllodocidae } & \text { Pirakia punctifera (Grube, 1860) }\end{array}$

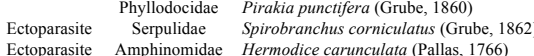

Ectoparasite Serpulidae Hydroides elegans (Haswell, 1883)

$\begin{array}{ll}\text { Serpulidae } & \text { Filograna sp. } \\ \text { Serpulidae } & \text { Spirobranchus triqueter (Linnaeus, } 1758)\end{array}$

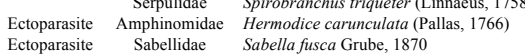

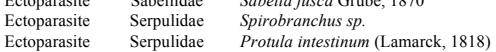

$\begin{array}{lll}\text { Ectoparasite } & \text { Serpulidae } & \text { Serpula vermicularis Linnaeus, } 1767 \\ \text { Ectoparasite } & \text { Sabellidae } & \text { Sabellas ap p }\end{array}$

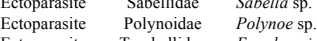

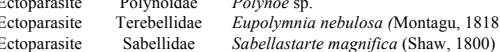

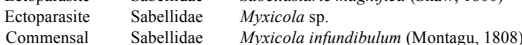

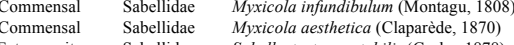

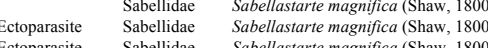

$\begin{array}{lll}\text { Ectoparasite } & \text { Sabellidae } & \text { Sabellastarte magnifica (Shaw, } 1800 \\ \text { Ectoparasite } & \text { Sabellidae } & \text { Sabellastart magnifica (Shaw 1800) } \\ \text { Ectoparasite } & \text { Sabellidae } & \text { Sabella spallanzanini (Gmelin, 1791) }\end{array}$

Sabellidae Sabella pavonina Savigny, 1822

Ectoparasite Sabellidae Sabella spallanzanii (Gmelin, 1791)

$\begin{array}{lll}\text { Ectoparasite } & \text { Sabellidae } & \text { Bispira volutacornis (Montagu, 1804) } \\ \text { Ectoparasite } & \text { Sabellidae } & \text { Sabella sp }\end{array}$

$\begin{array}{lll}\text { Ectoparasite } & \text { Serpulidae } & \text { Pomatostegus stellatus (Abildgaard, 1789) } \\ \text { Ectoparasite } & \text { Serpulidae } & \text { Spirobranchus giganteus (Pallas, 1766) }\end{array}$

$\begin{array}{ccc}\text { Ectoparasite } & \text { Terebellidae } & \text { Terebella e hrenbergi Gravier, } 1906 \\ \text { Ectoparasite } & \text { Ampharetidae } & \text { Melinna cristata (Sars, 1851) }\end{array}$

$\begin{array}{lll}\text { Ectoparasite } & \text { Ampharetidac } & \text { Melinna cristata (Sars, } 1851 \text { ) } \\ \text { Ectoparasite } & \text { Terebellidae } & \text { Ehlersiella altantica Mclntosh, } 1885\end{array}$

Ectoparasite Trichobranchidac Terebellides stroemi Sars, 1835
Ectoparasitie
Trichobranchidae

$\begin{array}{ccc}\begin{array}{c}\text { Ectoparasite } \\ \text { Ectoparasite }\end{array} & \begin{array}{c}\text { Flabelligeridae } \\ \text { Tercebllidae }\end{array} & \begin{array}{c}\text { Flabelligera diplochaitos (Otto, 1821) } \\ \text { Eupolymnia nebullosa (Montagu, 1818 }\end{array}\end{array}$

$\begin{array}{ccc}\begin{array}{c}\text { Ectoparasite } \\ \text { Ectoparasite }\end{array} & \begin{array}{c}\text { Terebellidae } \\ \text { Serpulidae }\end{array} & \begin{array}{c}\text { Eupolymnia nebulosa } \\ \text { Unknown }\end{array} \\ & & \end{array}$

Ectoparasite Serpulidae Josephella sp.

$\begin{array}{lll}\begin{array}{ll}\text { Ectoparasite } \\ \text { Ectoparasite }\end{array} & \begin{array}{l}\text { Serpulidae } \\ \text { SSrpulidac }\end{array} & \begin{array}{l}\text { Placostegus tridentatus (Fabricius, 1779) } \\ \text { Apomatus sp. }\end{array}\end{array}$ $\begin{array}{lll}\text { Ectoparasite } & \text { Serpulidae } & \text { Salmacina setosa Langerhans, } 1884 \\ \text { Ectoparasite } & \text { Serpulidae } & \text { Undescribed }\end{array}$
Bis Denmarck

$30 \mathrm{~m} \quad \begin{aligned} & \text { Indian Ocea } \\ & \text { Sudafrica }\end{aligned}$

Sudafrica
Golfe Guiné (Atlantic)

Kattegat
Denmark and Swede

$\begin{array}{ll}102 \mathrm{~m} & \begin{array}{l}\text { Norway } \\ 12-15 \mathrm{~m}\end{array} \\ \text { Black Sea }\end{array}$

$\begin{array}{cc}2,000-3,000 \mathrm{~m} & \text { Mediterranean } \\ 13 \mathrm{~m} & \text { Mediterranean } \\ & \end{array}$

low tidal Grat Barrier Reef

Mediterranean

Mediterran

Mediterraneaa
Meditrranear
Sederyes

US Virgin Islands; western Caribbean and in Mexican waters

Scotland, Italy, Sri Lanka, England, sweden, Norway

British waters
British waters

Jamaica
Indian Ocean, Red Sea

Naples, Italy: Banyuls, France: Strangford Lough, Northern Ireland

Banuyls, France
British waters

British waters
Rogish Channel
Roscoff

Yellow sea
Plymouth; Roscoff

Nosy Be, Madagascar

Nosy Be, Madagascer

Nosy Be, Madagaser

Nosy Be, Madagaserer

Norway, Sweden, Northern Ireland, Ireland, England, France, Italy,

Saint George Chanel; British and European water

British waters to Mediterranean Sea

Arraçao, Bonaire, Puerto Rico, Jamaica, Barbados, Bahamas

Yellow Sea

Scandinavian waters, Massachussetts
Atlantic Ocean, between Bermuda and Azores

off Greenland and northern North America
off Greenland and northern North America; Mediterranean

Mediterranean
North Sea, Norway

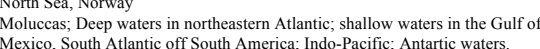

North Atlantic Ocean
Eastern Gulf of Mexico

North Atlantic Ocean
North Atlantic Ocean

North Atlantic Occan
Indonesia
Bresciani (1967), host as Anthinoe sarsi (Théel, 1879)

Bresciani
OReilly (1995)

Bresciani $(1967)$
Bresciani (1967)

Stock (1986), host as Harmothoe corralophila Day, 1960

Stock (1996)
Carton \& Laubier (1974)

Carton \& Laubier (1974), host as Hermadion rouch G Gravier,

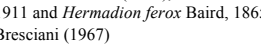

O'Reilly (1991)) Kim et al. (2013)
O'Reilly (1991): Kim et al (2013)

Laubier \& Carton (1973), host as Aricidea jeffreysi [Auct. (No

McIntosh, 1879)]
Laubier \& Carton (1973)
Kim et al (2013)

Boxshall \& Hasley (2004), host as Leanira areolata McIntosh.

1885
Stock (1988)

Delamare-Deboumeville \& Laubier, 1961, host as Eulalia pusill
Drstedt 1843

Delamare-Deboutteville \& Laubier (1960, 1961); : Laubier (1961 Delamare-Deboutteville \& Laubier $(1960,1961)$; Laubier $(196)$ Delamare-Deboutteville \& Laubier (1960, 1961); Laubier (1961)
Delamare-Deboutteville \& Laubier (1960, 1961); Laubier (1961) Stock et al. (1964); Yáñez-Rivera et al. (2008)

Costanzo et al. (1996)

O'Reilly (1991)
O'Reilly (1991),

Pomatoceros triqueter (Linnaeus, 1758

Stock et al (1964)
Humes \& Ho (1967)

Stock (1995)
Stock (1959)

Stock (1960)
O'Reilly (1991)

Bocquet et al. (1963)

O'Reilly (1991)
Humes (1975)

Kim (2001a)

Boccquet \& Stock (1958)

Humes \& Ho (1967)

Humes \& Ho (1967)

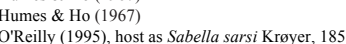

O'Reilly (1995)

O'Reilly (1995), host as Spirographis spallanzani (Viviani, 1805)

Humes (1975)
Humes (1975)

Humes \& Stock (1973)
Humes \& Stock (1973)

Kim (2001a)

Bresciani \& Lützen (1974a)
Bresciani \& Lützen (1974a)

Bresciani \& Lützen (1974a)
Bresciani \& Lützen (1974a)

Gravier (1918a, b); Mariniello (2010)
Laubier (1970)

Laubier (1970)
Humes (1985)

Southward (1964)
Stock (1979)

Stock (1979)
Humes \& Grassle (1979)
Southward (1964), host a

963 ard (1964), host as Omphalopoma stellata Southward,

1963
Southward (1964)
Stock (1989) 
Spiophanicola spinosus Ho, 1984

$\begin{array}{ll}\text { Spiophanicolidae } & \begin{array}{l}\text { Spiophanicola atlanticus Kim, Sikosky, O'R } \\ \text { Xenocoelomatidae }\end{array} \\ \text { Aphanodomus terebellae (Levinsen, 1878) }\end{array}$

Xenocoelomatidae $\quad$ Xenocoeloma alleni (Brumpt, 1897)

$\begin{array}{ll}\begin{array}{l}\text { Xenocoelomatidae } \\ \text { Xenocoelomatidae }\end{array} & \begin{array}{l}\text { Xenocoeloma brumpti Caullery \& Messil, } 1915 \\ \text { Xenocoeeloma sp. }\end{array}\end{array}$

\section{Incertae sedis
(Pocecilostomatoida) Stockella indica (Sebastian \& Pillai, 1974)}

Incertas sedis
(Poocilostomatoida) Cyclorhiza eteonicola Heegaard, 1942

Incertae sedis
(Poecilostomatoda) Cyclorhiza megalova Gotto \& Leahy, 1988

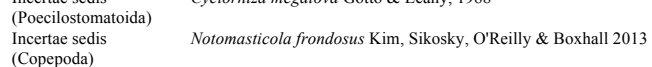

Incertae sed

(Copepoda)
Incertac sedia
(Cyclopoida)

Notomasticola frondosus Kim, Sikosky, O'Reilly \& Boxhall 2013

Ophelicola drachi Humes, 1978

Ophelicola kurambia sp. nov.
Ectoparasit

Ectoparasite

Serpulidae Hyalopomatus macintoshi (Gravier, 1911)

$\begin{array}{ll}\begin{array}{c}\text { Spionidae } \\ \text { Spionidae }\end{array} & \begin{array}{l}\text { Spiophanes berkeleyorum Pettibone, 1962 } \\ \text { Spiophanes duplex (Chamberlin, 1919) }\end{array}\end{array}$

$\begin{array}{ll}\text { Spionidae } & \text { Spiophanes kroverir Grube, } 1860 \\ \text { Spionidae } & \text { Spiophanes troveri Grube, } 1860\end{array}$

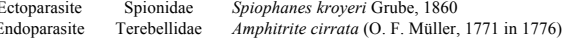

Tercbellidae Artacama probossidea Malmgren, 1866

$\begin{array}{ll}\text { Terebellidae } & \text { Lanasa venusta (Malm, 1874) } \\ \text { Terebellidae } & \text { Nicolea zostericola Örsted, 1844 }\end{array}$

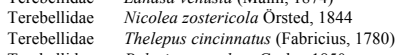

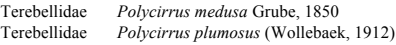

Ectoparasite

$\begin{array}{lll} & \text { Terebellidace } & \text { Polycirrus plumosus (Wollebaek, 1912) } \\ \text { Ectoparasite } & \text { Terebellidae } & \text { Polycirus surenivorus (Caullery, 1915) } \\ \text { Ectoparasite } & \text { Terebellidae } & \text { Polvcirrus arcticus Sars, 1865 }\end{array}$

Tolycirns caliendrum Claparéde, 1869

Ectoparasite Phyllodocidae Eteone longa (Fabricius, 1780)

Ectoparasite Phyllodocidae Eteone longa (Fabricius, 1780)

Endoparasite Spionidae $\quad$ Pseudopolydora paucibranchiata (Okuda, 1937)

Endoparasite Capitellidae Notomassus latericius Sars, 1851

Ectoparasite Ophelidae Unknown

Ectoparasite Ophelidae Unknown
Antarctic Ocean

west coast of southern of California
west coast of southern of California

west coast of southern of California

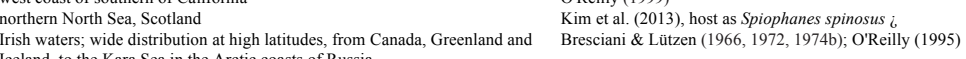

Iceland

Iceland
Scandinavia
East Greenland

English Channel
French coasts

English Channel

Greenland
Hong Kong
Indian Ocean

North Atlantic and Medititranean (Lower St Lawrence estuary, Isle of Man,
Northeast England, West Norway, eastern North

British waters

$133 \mathrm{~m} \quad$ Europe

$125 \mathrm{~m} \quad$ Europe

$4.500 \mathrm{~m} \quad$ Bay of Bisscay (abyssal plain)

4,987-4,991 $\mathrm{m} \quad$ Kurile Kamchatka Trench and abyssal plain
Gravier (1912b), host as Cystopomatus macintoshi Gravier, 191

Ho (1984)

'Reilly (1999)

Bresciani \& Lützen (1966, 1972, 19746)

Bresciani \& Lützen (1966, 1972, 1974b)
Bresciani \& Lutzen (1966, 1972, 1974b)
Bresciani \& Lutzen $(1966,1972,1974 b)$

O'Reilly (1995)
Bresciani \& Lutren (1966, 1972, 1974b);

Brumpt (1897); Bresciani \& Lutzen (1) (1966, 1972, 1974b);
Brumt (1897); Bocguet tet al (1968)

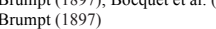

Bresciani \& Lützen (1966)
Bresciani \& Lützen (1974b)

Bresciani \& Lützen (1974)
Boxshall (2001)
Sebastian \& Pillai (1974)

Gotto \& Leahy (1988)

Gotto \& Leahy (1988) ; O'Reilly (1991)

Kim et al. (2013)

Kim et al. (2013)

Laubier (Laubier, 1978)

This paper 